\title{
Insigths of sphalerite weathering under simulated acidic, circumneutral and alkaline conditions to account for mineral activity and potential $\mathrm{Zn}$ release
}

\section{Fabiola S Sosa-Rodríguez}

Universidad Autonoma Metropolitana Azcapotzalco

Jorge Vázquez-Arenas

Instituto Politecnico Nacional

Patricia Ponce-Peña

Universidad Juarez del Estado de Durango

Antonio Aragón-Piña

Universidad Autonoma de San Luis Potosi

Martine Mallet

Universite de Lorraine

\section{Gabriel Trejo-Córdova}

CIDETEQ: Centro de Investigacion y Desarrollo Tecnologico en Electroquimica SC

Diola M Núñez-Ramírez

Universidad Juarez del Estado de Durango

Miguel A Escobedo-Bretado

Universidad Juarez del Estado de Durango

René Homero Lara ( $\square$ lcrh75@hotmail.com )

Universidad Juarez del Estado de Durango https://orcid.org/0000-0003-0985-9594

\section{Research Article}

Keywords: Sphalerite oxidation, Structure-activity relationships, Oxidation mechanisms, Simulated weathering, Non-conventional Tafel analysis, Marmatite-like sphalerite

Posted Date: January 18th, 2022

DOI: https://doi.org/10.21203/rs.3.rs-1160353/v1

License: (c) (1) This work is licensed under a Creative Commons Attribution 4.0 International License.

Read Full License 
1 Insigths of sphalerite weathering under simulated acidic,

2 circumneutral and alkaline conditions to account for mineral

\section{3 activity and potential $\mathrm{Zn}$ release}

4 Fabiola S. Sosa-Rodríguez ${ }^{\mathrm{a}}$, Jorge Vazquez-Arenas $^{\mathrm{b}}$, Patricia Ponce-Peña ${ }^{\mathrm{c}}$, Antonio

5 Aragón-Piña ${ }^{\mathrm{d}}$, Martine Mallet $^{\mathrm{e}}$, Gabriel Trejo-Córdova ${ }^{\mathrm{f}}$, Diola M. Núñez-Ramirez $^{\mathrm{c}}$,

6 Miguel A. Escobedo-Bretado ${ }^{\mathrm{c}}$, René H. Lara ${ }^{\mathrm{c}, ~ *}$

7 a Research Area of Growth and Environment, Metropolitan Autonomous University (UAM-A),

8 Azcapotzalco, Av. San Pablo 180, Mexico City, 02200, Mexico.

9 b Centro Mexicano para la Producción más Limpia (CMP+L), Instituto Politécnico Nacional, Av.

10 Acueducto s/n, Col. La Laguna Ticomán, Ciudad de México, 07340, Mexico.

$1{ }^{c}$ Department of Materials Science, Faculty of Chemical Sciences, Universidad Juárez del Estado de

12 Durango (UJED), Av. Veterinaria S/N, Circuito Universitario, 34120, Durango, DGO, Mexico.

13 d Institute of Metallurgy, Autonomous University of San Luis Potosí (UASLP), Av. Sierra Leona 550,

14 Lomas 2da, 78210, San Luis Potosi, SLP, Mexico.

15 e Université de Lorraine, CNRS, LCPME, F-54000 Nancy, France.

$16{ }^{\mathrm{f}}$ Centro de Investigación y Desarrollo Tecnológico en Electroquímica (CIDETEQ), Parque Tecnológico

17 Sanfandila, Querétaro, 76703, Mexico. 
23 The present study combines surface analyses of pristine and leached low Fe-bearing and $\mathrm{Pb}$ 24 bearing sphalerite (PbS-ZnS) samples including XPS, GDOES, Raman spectroscopy, SEM and 25 AFM, along with chemical evolution of leachates after $24 \mathrm{~h}$ of contact with $0.1 \mathrm{M} \mathrm{NaOH}, 0.1 \mathrm{M}$

$26 \mathrm{NaNO}_{3}, 0.1 \mathrm{M} \mathrm{H}_{2} \mathrm{SO}_{4}$ or $0.1 \mathrm{M} \mathrm{HClO}_{4}$ solution. A comprehensive electrochemical analysis using 27 Cyclic voltammetry, Chronopotentiometry, Chronoamperometry, Linear sweep voltammetry and 28 Tafel plots of $\mathrm{PbS}-\mathrm{ZnS}$ and marmatite-like sphalerite (FeZnS) are conducted to compare its 29 oxidation activities. Mineral characterizations reveal sluggish weathering linked to 30 inhomogeneous and minor secondary polysulfides $\left(S_{n}{ }^{2-}\right)$ surface compounds distribution, thus 31 defining bare modifications of surface-activity relationships. The occurrence of secondary $\mathrm{Zn}$ -

32 bearing compounds was not identified on altered samples, which suggests that this heavy metal 33 diffuses into the bulk-solution. Electrochemical assessments confirm sluggish sphalerite 34 oxidation mainly composed by two subsequent stages, where the highest mineral activity was 35 obtained in $\mathrm{NaOH}$ conditions. It was found that the sphalerite oxidation is more active in the 36 presence of $\mathrm{Pb}$, while the activity of sphalerite gradually decreases when it is a mineral rich in $\mathrm{Fe}$ 37 probably associated with progressive accumulation of $\mathrm{S}_{n}{ }^{2-} / \mathrm{S}^{0}$ compounds. We suggest general 38 oxidation mechanisms for sphalerite, and their environmental implications are discussed.

41 Key words: Sphalerite oxidation; Structure-activity relationships; Oxidation mechanisms;

42 Simulated weathering; Non-conventional Tafel analysis; Marmatite-like sphalerite. 


\section{Introduction}

46 Mining industry is still a global source of air, water and soil pollution since it typically generates

47 important amounts of waste (i.e., tailing impoundments, dumps and hard rock deposits), without

48 an apparent control of spillage (Zhao et al. 2020; Myagkaya et al. 2021). Mining waste usually

49 contains significant amounts of metal sulfide (MS) grains, which are present as free and/or

50 occluded minerals in bulk, whence they are easily dispersed by eolic and/or pluvial processes

51 highlighting environmental and health risks due to release of potentially toxic elements (i.e., As,

$52 \mathrm{~Pb}, \mathrm{Cr}, \mathrm{Co}, \mathrm{Ni}, \mathrm{Zn}, \mathrm{Cu}, \mathrm{Hg}$ ) (Punia 2021; Myagkaya et al. 2021). Among the main MS causing

53 these problems are pyrite $\left(\mathrm{FeS}_{2}\right)$, pirrothite $\left(\mathrm{Fe}_{1-\mathrm{x}} \mathrm{S}\right)$, sphalerite $(\mathrm{ZnS})$, galena $(\mathrm{PbS})$, chalcopyrite

$54\left(\mathrm{CuFeS}_{2}\right)$, and arsenopyrite (FeAsS) (Scoble et al. 2003; Lottermoser 2010). To this concern,

55 arsenopyrite and galena have been mostly evaluated due to potential toxicity, and evident role in

56 As and/or $\mathrm{Pb}$ mobility during environmental mineral weathering ( $\mathrm{Lu}$ et al. 2011; Gamiño-

57 Gutiérrez et al. 2013). In contrast, among the least studied MS is sphalerite, exhibiting diversity

58 of mineral $\mathrm{ZnS}$ phases with varied $\mathrm{Fe}$ amounts (i.e., marmatite-like) and impurities (i.e., galena).

59 These changes in structure significantly modify mineral weathering and the resulting $\mathrm{Zn}$ release

60 with bare understanding of the reaction pathways, translocation of mobile $\mathrm{Zn}$ from soil to

61 biomass and environmental distribution behavior (Robson et al. 2014; Shabbir et al. 2021).

62 Examples of industrial, urban, forest and agricultural sites (and regions) with impacts generated

63 by the occurrence of sphalerite spillage include Mexico, The USA, North China, West and

64 Central Europe, among others, presenting different type of soil (i.e., saline, alkaline or acidic) and

65 climatic conditions (Hita and Torrent 2005; Acero et al. 2007; Álvarez-Ayuso et al. 2013;

66 Gamiño-Gutiérrez et al. 2013; Voldrichova et al. 2014; Li et al. 2014; Lu et al. 2019). Sphalerite

67 oxidation is then global pollution problem for sites affected by mining waste alteration or spillage

68 to soil, which threatens the sustainability of the local environment and human health. 
69 Low-Fe bearing $(\sim 4.5 \%)$ sphalerite samples present high-electrical resistivity $\left(\sim 10^{10} \Omega\right)$ (Ahlberg

70 and Ásbjörnsson 1994; Crundwell 2021), which hamper the analysis of their redox behavior 71 using electrochemical methods, whereby its study is typically limited to chemical and

72 mineralogical analysis. An indirect way of studying this type of sphalerite has been through the

73 study of samples that presents reactive impurities such as galena or high Fe content in structure

74 (Giudici et al. 2002; Da Silva et al. 2003; Urbano et al. 2007). The study of environmental

75 sphalerite oxidation has been focused mainly towards understanding the weathering process when

76 it is contained in acidity-generating Zn-bearing mining wastes (Langman and Moberly 2018; Bao

77 et al. 2021), when it is altered in an environment where it is easily disturbed by the (bio)oxidation

78 of mining wastes (Chen et al., 2009; Langman and Moberly, 2018), or when fine-particulate Zn-

79 bearing minerals are generated increasing incidental ingestion and/or inhalation exposure

80 (Thomas et al., 2018). Additionally, neutralization and precipitation processes, dissolution of

81 gangue materials, uncontrolled dissolution reactions of concomitant MS, the progressive

82 modification of chemical environment and/or the occurrence of significant amounts of PTEs in

83 systems, among others, have hampered a comprehensive assessment of the interfacial

84 mechanisms of sphalerite. For this reason, the interfacial insigths of sphalerite oxidation are not

85 yet well known, as well as the stages that make them up, or considering the effect of different

86 types of sphalerite (i.e., marmatite-like, low-Fe and $\mathrm{Pb}$-bearing specimens) on the stability of the

87 oxidation products and the relationships that these processes have with its oxidation capacity,

88 thus improving our knowledge of processes controlling the release of $\mathrm{Zn}$ in crops, mining, forest

89 regions, urban and farming areas due to oxidation of primary sources of Zn (Razo et al. 2004;

90 Hofmann and Schuwirth 2008; Gamiño-Gutiérrez et al. 2013; Lu et al. 2019). 
93 The aim of the present study is to describe interfacial insigths and activity regarding sphalerite 94 oxidation to elucidate the main weathering mechanisms under typical environmental conditions 95 (i.e., $\mathrm{H}_{2} \mathrm{SO}_{4}, \mathrm{NaNO}_{3}, \mathrm{NaOH}, \mathrm{HClO}_{4}$ ), the role of secondary products (i.e., $\mathrm{ZnO}_{2}, \mathrm{~S}_{n}{ }^{2-}, \mathrm{S}^{0}$ ), and 96 surface-activity relationships, among others. In order to achieve this goal, a combination of

97 spectroscopic (Raman Spectroscopy, X-ray Diffraction Patterns (XRD), Glow Discharge Optical 98 Emission Spectroscopy (GDOES), X-ray Photoelectron Spectroscopy(XPS)) and microscopic 99 (Scanning Electron Microscopy (SEM), 2D-3D, Atomic Force Microscopy(AFM)) techniques 100 along with chemical analysis of leachates (sulfates, ORP, $\mathrm{pH}$ and $\mathrm{Zn}, \mathrm{Cd}, \mathrm{Fe}$ determinations) are 101 carried out using $\mathrm{PbS}-\mathrm{ZnS}$ samples. A comprehensive electrochemical assessment (Cyclic 102 voltammetry, Chronoamperometry, Chronopotentiometry, Linear sweep voltammetry, Tafel 103 plots) is also conducted to simulate charge transfer and oxidation processes of $\mathrm{PbS}-\mathrm{ZnS}$ and 104 marmatite-like sphalerite during weathering. We expect these findings contribute to better 105 understand the complex sphalerite oxidation and reactions, to improve the accuracy of predictions 106 about the environmental fate of $\mathrm{Zn}$ due to primary sources oxidation, and the design of more 107 efficient restoration methods (and mining practices) in benefit of urban, forest regions and agricultural polluted areas with $\mathrm{Zn}$ occurrence, distribution and release in the environment.

\section{Materials and methods}

\subsection{Mineral samples}

112 Sphalerite massive samples were obtained from different sites to cover most important sphalerite 113 specimens. A low Fe-bearing and Pb-bearing sphalerite sample referred as $\mathrm{ZnS}$-PbS samples was 114 purchased from Excalibur minerals Corp. (Charlottesville, VA, USA) (Electronic Supplementary 115 Material, ESM, Fig. S1a). Additionally, a marmatite-like sphalerite referred as FeZnS sample 116 was obtained from the mining district of Charcas (San Luis Potosí, Mexico; ESM, Fig. S1b). 
117 After careful selection, sphalerite crystals were reduced to 3-5 $\mathrm{mm}$ size. Grains were then rinsed

118 with an acidic solution $(\mathrm{HCl}, 3 \% \mathrm{v} / \mathrm{v})$, washed with deionized water, and dried with direct $\mathrm{N}_{2}$

119 current. The samples were also stored in a $\mathrm{N}_{2}$ atmosphere until they were grinded using an agate

120 mortar and sieved to fraction size <106 $\mu \mathrm{m}$ under inert conditions for mineralogical and

121 electrochemical studies. X-ray diffraction patterns (Rigaku DMAX 2200, 20=0.02, from $10^{\circ}$ to

$12290^{\circ}$, using $\mathrm{Cu}-\mathrm{K} \alpha$ radiation) and elemental chemical analysis using atomic emission spectroscopy

123 (Agilent MP-AES-4100 atomic emission spectrometer) were measured to verify the

124 mineralogical identity and composition of the samples. Selected $\mathrm{PbS}-\mathrm{ZnS}$ crystals were used for

125 the construction of rectangular mineral pieces (dimensions $0.4 \mathrm{~cm}$ width, $0.6 \mathrm{~cm}$ length, $0.4 \mathrm{~cm}$

126 depth) to analyze with AFM and GDOES techniques.

\section{$128 \quad$ 2.2. Electrochemical study}

129

$\mathrm{PbS}-\mathrm{ZnS}$ and FeZnS samples were used during electrochemical assessment using carbon paste electrodes (CPE). These CPE were constructed and utilized as indicated elsewhere (Svancara et al. 2001). Mineral grains of $\mathrm{PbS}-\mathrm{ZnS}$ and FeZnS samples were characterized using a SP-150 Biologic potentiostat/galvanostat system coupled to a personal computer. A three-electrode cell

133 system was used: a carbon paste electrode which contains $\mathrm{PbS}-\mathrm{ZnS}$ and/or FeZnS particles 134 (50/50 wt. \%) as the working electrode, a graphite rod (AlfaAesar, $99.9995 \%$ purity) as the 135 counter electrode, and a saturated calomel electrode (SCE) as the reference (0.244 V vs. SHE). 136 The amount of sphalerite selected is based on achieve an adequate electrical percolation process 137 of the sphalerite-bearing carbon paste system (Ahlberg and Ásbjörnsson 1994; Giudici et al. 138 2002; Da Silva et al. 2003). Different solutions were tested during electrochemical experiments to 139 simulate typical environment weathering conditions, which were prepared using analytical grade 
reagents (JT Baker) and mili-Q deionized-water $\left(18.2 \mathrm{M} \cdot \mathrm{cm}^{-1}\right)$. These solutions are $0.1 \mathrm{M} \mathrm{H}_{2} \mathrm{SO}_{4}$ $(\mathrm{pH}=1.4), 0.1 \mathrm{M} \mathrm{NaOH}(\mathrm{pH}=13.3), 0.1 \mathrm{M} \mathrm{NaNO}_{3}(\mathrm{pH}=6.6)$ and $0.1 \mathrm{M} \mathrm{HClO}_{4}(\mathrm{pH}=1.6)$.

143 Cyclic voltammetry $(\mathrm{CV})$ was then initiated in the positive and negative direction at $5 \mathrm{mV} \cdot \mathrm{s}^{-1}$. 144 Additionally, a study of the variation of the positive potential limit $\left(\mathrm{E}_{\lambda \pm}\right)$ was carried out to 145 evaluate the stages of the corresponding oxidation process. Chronoamperometry (CA) and/or 146 Chronopotentiometry (CP) were carried out using most significant anodic potentials or currents 147 in agreement with the $\mathrm{CV}$; in order to apply potential $\left(\mathrm{E}_{a}\right)$ and/or current $\left(\mathrm{I}_{a}\right)$ pulses during $600 \mathrm{~s}$. 148 Tafel plots (TP) were obtained using linear sweep voltammetry scans (LSV) using RDE Pine 149 system at $1 \mathrm{mV} \cdot \mathrm{s}^{-1}$ and stirring conditions of $300 \mathrm{rpm}$. TP were carried out using a stainless steel 150 electrode jacketed with Teflon to generate a hole, where the carbon paste containing $\mathrm{PbS}-\mathrm{ZnS}$ 151 and/or FeZnS was placed (ESM, Fig. S2). The open circuit potential $\left(\mathrm{OCP}_{i=0}\right)$ was monitored 152 before CV, CA, CP, TP and LSV studies which was situated within $\pm 20 \mathrm{mV}$ in all conditions 153 tested (i.e., after $\sim 400 \mathrm{~s}$ for $\mathrm{OCP}_{i=0}$ stabilization under $0.1 \mathrm{M} \mathrm{HClO}_{4}$ ). The effect of the altered 154 mineral surfaces (i.e., secondary products) on the $\mathrm{PbS}-\mathrm{ZnS}$ and FeZnS activities was also 155 evaluated. These experiments consisted of applying $\mathrm{E}_{a}=1.2 \mathrm{~V} / \mathrm{SCE}$ during 1 and/or $2 \mathrm{~h}$ to the 156 pristine samples to generate secondary compounds layers, which was followed by LSV on the 157 positive direction at $20 \mathrm{mV} \cdot \mathrm{s}^{-1}$ using all tested solutions. The comparison between LSV curves 158 from pristine and oxidized samples, allowed inferring about evolution of mineral activity (i.e., 159 oxidation capacity). 
164 Leaching devices were used to promote a simplified $\mathrm{PbS}-\mathrm{ZnS}$ oxidation process under simulated 165 weathering conditions (Schippers et al. 2019). PbS-ZnS grains were selected in the present study 166 due to mineral availability: $10 \mathrm{~g}$ of $\mathrm{PbS}-\mathrm{ZnS}$ grains (i.e., <106 $\mu \mathrm{m}$ ) were placed in Erlenmeyer 167 flasks containing in each case $250 \mathrm{~mL}$ of the same $0.1 \mathrm{M} \mathrm{H}_{2} \mathrm{SO}_{4}, 0.1 \mathrm{M} \mathrm{NaOH}, 0.1 \mathrm{M} \mathrm{NaNO}_{3}$ or $0.1 \mathrm{M} \mathrm{HClO}_{4}$ solution during $24 \mathrm{~h}$ at $30 \mathrm{rpm}$ (ambient conditions). Experiments were carried out 169 at duplicate. $5 \mathrm{~mL}$ of leachates were obtained from each leaching device every $3 \mathrm{~h}$ to determine $170 \mathrm{pH}$, oxidation-reduction potential (ORP), sulfates (i.e., $\mathrm{SO}_{4}{ }^{2-}$ ), and total $\mathrm{Zn}$, $\mathrm{Fe}$ or $\mathrm{Cd}$ 171 concentrations. A sample of leached mineral was taken after $24 \mathrm{~h}$, dried with direct current of $\mathrm{N}_{2}$ 172 and kept under vacuum for mineralogical characterizations. Additionally, a leaching experiment 173 of sphalerite in $0.1 \mathrm{M} \mathrm{H}_{2} \mathrm{SO}_{4}$ conditions was carried out after $240 \mathrm{~h}$ to obtain a more altered 174 sample aimed at one of the studied systems to further analyze with XPS for comparison purposes.

\subsection{Chemical analyses of leachates}

177 The total $\mathrm{Zn}, \mathrm{Fe}$ and $\mathrm{Cd}$ were analyzed using atomic absorption spectroscopy with graphite 178 furnace (AAS-GF, Perkin Elmer 3100 atomic absorption spectrometer) with a 179 detection/quantification limit of $0.1 / 0.15,0.1 / 0.15$ and $0.05 / 0.1 \mathrm{mg} \cdot \mathrm{L}^{-1}$, respectively. As a quality 180 control, SRM 1643D (NIST, USA) trace element in water standard reference material was used.

181 The percentage recovery values were better than $95 \%$ in all cases. Calibration of instruments, 182 blank correction, matrix effects, sample manipulation, and operating conditions met national and 183 international criteria (Eaton et al. 1995; DOF 2007). Sulfate determinations were carried out 184 using turbidimetric method with $\mathrm{BaCl}_{2}$ and an UV-1900 UV-Vis Agilent spectrophotometer, 185 according to SW-846-9038 test method (USEPA 1986). The $\mathrm{pH}$ and ORP were measured using a 186 Hanna HI-2211 pH-meter. 
Pristine and leached $\mathrm{PbS}-\mathrm{ZnS}$ samples were characterized using microscopic (SEM, AFM) and spectroscopic techniques (XPS, GDOES, XRD and Raman). Scanning electron microscopy was conducted using a JEOL JSM-6610LV with an energy dispersive detector Oxford X-MAX for 191 chemical analysis (SEM-EDS). XRD was carried out using a Rigaku DMAX 2200, (20=0.02, from $10^{\circ}$ to $90^{\circ}$ ) using $\mathrm{Cu}-\mathrm{K} \alpha$ radiation. Raman spectra were recorded with a Horiba XploRA ${ }^{\mathrm{TM}}$ PLUS spectrometer coupled with a SWIFT ${ }^{\mathrm{TM}}$ v2 confocal imaging module which used a solidstate laser beam $(\lambda=532 \mathrm{~nm})$. A Si wafer disc (i.e., $\left.521 \mathrm{~cm}^{-1}\right)$ was used for calibration purposes. At least 10 Raman spectra were collected for each sample. The X-ray photoelectron spectroscopy 196 (XPS) analysis was performed using a KRATOS Axis Ultra (Kratos Analytical, UK) spectrometer equipped with a monochromatized Al Ka X-rays source $(h v=1486.6 \mathrm{eV})$ running at a power of $150 \mathrm{~W}$. The pristine samples were milled and prepared under an argon atmosphere, 199 whereas the leached samples were prepared under ambient exposure. The basic pressure in the analytical chamber was about $10^{-9}$ mbar. Spectra were collected at a normal take-off angle $\left(90^{\circ}\right)$ 201 and the analysis area was $700 \times 300 \mu \mathrm{m}^{2}$. XPS survey spectra were recorded with $1.0 \mathrm{eV}$ step and $160 \mathrm{eV}$ analyzer pass energy, while narrow scans were recorded with $0.05 \mathrm{eV}$ step and $20 \mathrm{eV}$ pass energy. XPS spectra were then analyzed by the Vision software from Kratos (Vision 2.2.0) after subtraction of the background (Shirley baseline). Typical Gaussian-Lorentzian (70/30) functions were used for peak decomposition. Charge correction was carried out using the C $1 \mathrm{~s}$ core line, setting the adventitious carbon signal (H/C signal) to $284.6 \mathrm{eV}$. AFM study was carried out using a Nanosurf easy scan AFM 2 system using contact mode. AFM images (topographic and deflection modes) of at least 10 regions per surface were obtained. The silicon cantilever showed a free resonance frequency between 13 and $15 \mathrm{kHz}$ and a constant of $0.2 \mathrm{~N} \mathrm{~m}^{-1}$ during 210 these experiments. Average roughness $(\mathrm{Ra}, \mathrm{nm})$ and root mean square roughness $(\mathrm{Rq}, \mathrm{nm})$ of 
each altered surface were also evaluated to obtain topographic information associated with

212 secondary compounds (Table 1). GDOES analyses were performed using a glow discharge 213 optical emission spectrometer Horiba Scientific GD profiler 2 using a current of $50 \mathrm{~mA}$ and 1000

$214 \mathrm{~W}\left(140^{\circ} \mathrm{C}\right)$ under vacuum conditions $\left(\sim 10^{-5}\right.$ Torr $)$. The spectrometer had a focal length of 1000 $215 \mathrm{~nm}$ and configured with 40 simultaneous detectors for the different atomic emission lines. The 216 analytical area was $4 \mathrm{~mm}$ in diameter. 700 Volts and $20 \mathrm{~mA}$ were chosen for the excitation and 217 sputtering processes, respectively. Note that the use of this technique to investigate sphalerite 218 samples (i.e., intensity vs. erosion time profiles) is unprecedented to our current state of 219 knowledge. Therefore, it could provide a new perspective to account for the role of sphalerite 220 oxidation indicating specific modifications of the surface-bulk mineral structure (i.e., structure221 activity relationships).

\section{$223 \quad 2.6$ Pourbaix-type diagrams}

224 This diagram was calculated using the chemical equilibrium software package Medusa®, which 225 is based on free energy minimization algorithms reported by Eriksson (1979). The reactions and 226 equilibrium constants required by the software to calculate these diagrams are available in the 227 HYDRA database within the Medusa® software package (Puigdomenech 2015). Note that the 228 experimental data (i.e., equilibrium constants) used to calculate this diagram have not been 229 validated (i.e., speciation, solubility), since this is a very demanding work which is beyond the 230 scope of the present study. Therefore, this thermodynamic information is herein used as a rapid 231 and predictive tool to evaluate the stability of released and/or oxidized species when the $\mathrm{pH}$ is 232 varied as a function of potential (Fig. S14). 


\subsection{Mineralogical characterization of pristine samples}

237 Chemical analysis of the pristine PbS-ZnS and FeZnS samples were carried out (Figs. S1a, S1b), 238 revealing $97 \%( \pm 0.2)$ wt. \% sphalerite, $1.8( \pm 0.3)$ wt. \% galena and $1.2( \pm 0.3)$ wt. \% quartz $239\left(\mathrm{SiO}_{2}\right)$ for the PbS-ZnS sample. Additionally, this PbS-ZnS sample contained $\sim 4.5$ wt. \% Fe in 240 crystals, in agreement with SEM-EDS (data not shown). The presence of galena mainly as free 241 grain particles was confirmed as main impurity in this sample (Figs. S1c, S1d). The presence of $242 \mathrm{Cd}, \mathrm{Ni}, \mathrm{Pb}$ and $\mathrm{Mn}$ traces was determined by atomic absorption spectroscopy. Mineral identity of 243 the PbS-ZnS sample corresponded to the XRD pattern JCPDS card no. 77-2110. On the other 244 hand, chemical analysis of the pristine FeZnS sample showed $99.6( \pm 0.1)$ wt. \% sphalerite, and $2450.4( \pm 0.2)$ wt. \% chalcopyrite $\left(\mathrm{CuFeS}_{2}\right)$. This sample also contain $\sim 20$ wt. \% Fe in crystals, in 246 agreement with SEM-EDS (data not shown). The pure FeZnS sample corresponded to the XRD 247 pattern JCPDS card no. 89-4939. The presence of $\mathrm{Cd}, \mathrm{Ni}, \mathrm{Mn}$ and $\mathrm{Cu}$ traces was also determined 248 by atomic absorption spectroscopy.

\subsection{Chemical evolution of leachates}

251 Fig. 1 shows the pH (Fig. 1a), ORP (Fig. 1b), sulfates (Fig. 1c), total Zn, Fe and Cd 252 concentrations (Figs. 1d, 1e and 1f, respectively) during evolution of leachates. Chemical 253 evolution of $\mathrm{pH}$ and $\mathrm{ORP}$ suggest minor variations for sphalerite weathering in $\mathrm{NaOH}, \mathrm{HClO}_{4}$ 254 and $\mathrm{H}_{2} \mathrm{SO}_{4}$ solutions (Figs. 1a and $1 \mathrm{~b}$, respectively), which was attributed to bare sphalerite 255 weathering capacity. In contrast, evolution of $\mathrm{pH}$ was enhanced for the $\mathrm{NaNO}_{3}$ system after $15 \mathrm{~h}$ 256 whence $\mathrm{pH}$ changes are more evident (Fig. 1a, curve blue). Circumneutral conditions of the

$257 \mathrm{NaNO}_{3}$ system are significantly more prone to modification of $\mathrm{pH}$ whereby changes of this 258 parameter can occur due to equilibrium changes (Heidel et al. 2013). Zn dissolution was 
enhanced in $\mathrm{HClO}_{4}, \mathrm{H}_{2} \mathrm{SO}_{4}$ and $\mathrm{NaOH}$ solutions, while this process was lower in the $\mathrm{NaNO}_{3}$ system (Fig. 1d). A similar dissolution behavior was identified for Fe and $\mathrm{Cd}$ in all tested solutions (Figs. 1e and 1f). In general, these results reveal the first insigths of sphalerite weathering indicating a sluggish sphalerite oxidation in all tested conditions, which are consistent with other observations describing that dissolution rate of sphalerite (i.e., low-Fe bearing sample) depends mainly on $\mathrm{pH}$, temperature and size of particle, among others, thus generating low concentrations of $\mathrm{Zn}$ and sulfates in these systems (Weisener et al. 2003; Malmström and Collin 2004; Acero et al. 2007).

\subsection{Mineralogical analysis of samples}

Fig. 2 shows 2D and 3D AFM images obtained from sphalerite weathering system after 24 in 0.1

$270 \mathrm{M} \mathrm{NaOH}$ (Figs. 2b and 2b', respectively), $0.1 \mathrm{M} \mathrm{NaNO}_{3}$ (Figs. 2c and 2c', respectively), $0.1 \mathrm{M}$

$271 \mathrm{HClO}_{4}$ (Figs. 2d and 2d', respectively) and $0.1 \mathrm{M} \mathrm{H}_{2} \mathrm{SO}_{4}$ (Figs. 2e and 2e', respectively)

272 solutions. The $2 \mathrm{D}$ and $3 \mathrm{D}$ images for the pristine sample were also included for comparison

273 purposes (Fig. 2a and 2a', respectively). Table 1 shows a comparison of roughness $\left(\mathrm{R}_{a}, \mathrm{~nm}\right)$ and

274 Root mean square $\left(\mathrm{R}_{q}, \mathrm{~nm}\right)$ parameters for a complete description of the surface processes. Figs.

$2751 \mathrm{a}$ and 1a' and Table 1 exhibited in general smooth-flat surface corresponding to typical non276 altered mineral surfaces. In contrast, Figs. 2b' to 2e' and Table 1 showed clear evidence for 277 sphalerite weathering under all tested conditions. A varied grade of surface alteration consisting 278 of surface pitting, dissolution patterns and formation of sub-micro sized secondary structures was 279 observed (Figs. 2b-b' to 2e-e', Table 1). The formation and evolution of sub-micro sized surface 280 secondary structures has been typically attributed to sphalerite oxidation under different 281 weathering conditions (Giudicci et al. 2002; Tauson et al. 2010), but the report of the formation 282 of dissolution patterns on the mineral surface was unprecedented with AFM. Note that highest $\mathrm{R}_{a}$ 
$283(\mathrm{~nm})$ and $\mathrm{R}_{q}(\mathrm{~nm})$ parameters was determined for samples in $0.1 \mathrm{M} \mathrm{H}_{2} \mathrm{SO}_{4}$ solution revealing that 284 sphalerite oxidation occurring in these conditions are more prone to generate and accumulate 285 secondary compounds on altered surfaces (Fig. 2e and 2e', Table 1). On the other hand, the occurrence of mineral dissolution patterns indicated a different reactive behavior for the samples

287 obtained in $0.1 \mathrm{M} \mathrm{NaOH}$ (Fig. 2b'), $0.1 \mathrm{M} \mathrm{NaNO}_{3}$ (Fig. 2c') or $0.1 \mathrm{M} \mathrm{HClO}_{4}$ (Fig. 2d') solution

288 (Table 1). These behaviors confirm a sluggish sphalerite weathering process in agreement with 289 Fig. 1; however, there surface processes develop with minor accumulation of sub-micro sized 290 secondary products (Fig. 2e', Table 1) and the establishment of dissolution patterns on altered 291 sphalerite samples (Figs. 2b' to 2c', Table 1).

293 Fig. 3 shows 2D SEM images obtained from pristine (Fig. 3a) and leached PbS-ZnS samples in $2940.1 \mathrm{M} \mathrm{NaOH}$ (Fig. 3c), $0.1 \mathrm{M} \mathrm{NaNO}_{3}$ (Fig. 3d), $0.1 \mathrm{M} \mathrm{HClO}_{4}$ (Fig. 3e) and $0.1 \mathrm{M} \mathrm{H}_{2} \mathrm{SO}_{4}$ (Fig. 3f) 295 conditions. Additionally, a 3D SEM image is included from leached samples obtained in $\mathrm{NaOH}$ 296 solution (Fig. 3b). Identification of secondary phases was carried out based on EDS analysis $(n=$ 29710 points). Fig. S3 includes the rest of 3D SEM images obtained from leached samples treated 298 with $\mathrm{NaNO}_{3}, \mathrm{HClO}_{4}$ or $\mathrm{H}_{2} \mathrm{SO}_{4}$ solution. 3D images show in general a similar surface behavior as 299 illustrated in Fig. 3b, confirming a sluggish weathering processes of sphalerite samples whence it 300 was not identified homogeneous or visible alteration of mineral surfaces to form clusters with 301 secondary compounds in all tested solutions. However, SEM-EDS 2D images of leached samples 302 indicate that the weathering trend of the sphalerite occurs mainly with the modification of the 303 surface-bulk structure (i.e., surface-structure relationships) forming mineral rimmed particles 304 with different degree of alteration with the formation of $\mathrm{Zn}_{1-\mathrm{x}} \mathrm{S}$-like structures (Figs. 3c to $3 f$ ). 305 The best developed mineral rimmed particles were observed for the samples treated with $0.1 \mathrm{M}$ $306 \mathrm{NaOH}$ and $0.1 \mathrm{M} \mathrm{H}_{2} \mathrm{SO}_{4}$ solution. The findings presented in Figs. 1 to 3 clearly indicate that 
sphalerite oxidation involves sluggish surface weathering with the formation of minor and not308 homogenously sub-micro sized secondary compounds distributed allowing scant surface309 reactivity relationship in all tested systems (i.e., rimmed grain particles, surfaces with sub-micro 310 sized secondary phases or well defined dissolution patterns).

312 Fig. 4a shows the Raman spectrum of the pristine sphalerite sample with typical peaks reported at 313 180, 220, 298, 330 and $349 \mathrm{~cm}^{-1}$ (Kharbish 2007; Osadchii and Gorbaty 2010; Buzatu et al. 314 2013). A summary of the typical transitions described for Raman transitions of $\mathrm{S}$ and $\mathrm{Zn}$ was 315 given in Table S1, and they can be used for secondary compounds identification in the present 316 study. Raman peak obtained at $521 \mathrm{~cm}^{-1}$ for Si-wafer disc was included to illustrate optimal 317 conditions during collection of Raman peaks (Fig. 4b). Raman spectra obtained for leached 318 samples obtained in $0.1 \mathrm{M} \mathrm{NaOH}, 0.1 \mathrm{M} \mathrm{NaNO}_{3}, 0.1 \mathrm{M} \mathrm{HClO}_{4}$ or $0.1 \mathrm{M} \mathrm{H}_{2} \mathrm{SO}_{4}$ solution are 319 illustrated in Figs. 4c, 4d, 4e and 4f, respectively. These spectra showed additional peaks ranging 320 from 465 to $474 \mathrm{~cm}^{-1}$; which revealed the clear formation of polysulfides (i.e., $\mathrm{S}_{n}{ }^{2-}$ ) (Table S1). 321 Additionally, the absence of Raman peaks around $980 \mathrm{~cm}^{-1}$ was identified for leached samples, 322 indicating the minor or null formation of $\mathrm{Zn}$-bearing compounds for all tested conditions (i.e., $323 \mathrm{Zn}(\mathrm{OH})_{2}, \mathrm{ZnSO}_{4}, \mathrm{ZnCO}_{3}$, Table S1). The findings presented in Fig. 4 suggested the occurrence 324 of polysulfides (i.e., $\mathrm{S}_{n}{ }^{2-}$ ) as main secondary surface products under all tested conditions. 325 Interestingly, the presence of anglesite $\left(\mathrm{PbSO}_{4}\right)$-like phase was identified on galena free-particles 326 obtained from the recovered samples treated in $0.1 \mathrm{M} \mathrm{H}_{2} \mathrm{SO}_{4}$ condition. This result supports 327 evidence regarding the formation of secondary compounds on the main sulfide impurity of 328 sphalerite samples (i.e., galena, Fig. S4, Table S1). 
The chemical bonding and composition of sulfur and zinc species on sphalerite samples were

331 further examined using XPS. Fig. 5 shows the high-resolution spectra ( $\mathrm{Zn} 2 p$ and S2p) for pristine 332 and leached samples after $24 \mathrm{~h}$ in $0.1 \mathrm{M} \mathrm{NaOH}, 0.1 \mathrm{M} \mathrm{NaNO}_{3}, 0.1 \mathrm{M} \mathrm{HClO}_{4}$ or $0.1 \mathrm{M} \mathrm{H}_{2} \mathrm{SO}_{4}$ 333 solutions. Additionally, Figs. S5a and S5b exhibits respectively $\mathrm{S} 2 p$ and $\mathrm{Pb} 4 d$ spectra obtained 334 from leached sample after $240 \mathrm{~h}$ in $0.1 \mathrm{M} \mathrm{H}_{2} \mathrm{SO}_{4} 0.1 \mathrm{M}$ solution for comparison purposes. The 335 corresponding fitting parameters are given in Table 2, and a summary of typical binding energies 336 reported in the literature for main sulfur and zinc species are also given in Table S2. The Zn2p 337 spectrum of pristine sample presents one strong peak at $1021.28 \mathrm{eV}$ that typically corresponds to $338 \mathrm{Zn}(\mathrm{II})-\mathrm{S}^{2-}$ species in pristine lattices (Fig. 5, Tables 2 and S2). The absence of carbonate (from 339 C1s not shown) and sulfoxy-compounds (Fig. 5) suggests negligible occurrence of solid Zn340 bearing secondary compounds (i.e., $\mathrm{ZnO}_{2}, \mathrm{Zn}(\mathrm{OH})_{2}, \mathrm{ZnCO}_{3}, \mathrm{ZnSO}_{4}$ ), in agreement with SEM341 EDS (Fig. 3) and Raman (Fig. 4) studies. The S2p spectrum in the pristine sample showed a major doublet, with a $2 p_{3 / 2}$ component located at $161.4 \mathrm{eV}$, commonly assigned to $\mathrm{S}^{2-}$ species in 343 mineral lattices (Fig. 5, Tables 2 and S2). A second minor doublet with $2 p_{3 / 2}$ component arising 344 at 162.9-163.3 $\mathrm{eV}$ was attributed to polysulfide species (i.e., $\mathrm{S}_{n}{ }^{2-}$ ), particularly for samples recovered in $0.1 \mathrm{M} \mathrm{NaOH}$ and $0.1 \mathrm{M} \mathrm{H}_{2} \mathrm{SO}_{4}$ systems (Fig. 5, Tables 2 and S2), thus, confirming 346 the results obtained during the Raman study (Fig. 4, Table S1). Note that S2p spectrum in Fig. 347 S5a clearly indicated a more advanced oxidation state for sulfur species since this spectrum was 348 obtained from the leached sample obtained after $240 \mathrm{~h}$ in $0.1 \mathrm{M} \mathrm{H}_{2} \mathrm{SO}_{4}$ solution, which reveals a 349 surface enrichment with $\mathrm{S}_{n}{ }^{2-} / \mathrm{S}^{0}$ compounds for a more advanced alteration stage of sphalerite 350 samples. It is important to highlight the absence of advanced oxidation states of the sulfur species 351 to form sulfoxy-compounds (i.e., $\mathrm{SO}_{4}{ }^{2-}, \mathrm{SO}_{\mathrm{x}}{ }^{2-}, \mathrm{S}_{2} \mathrm{O}_{3}{ }^{2-}$ ) retained on leached surfaces for all tested 352 conditions (Fig. 5, Table S2), which was consistent with numerous studies of altered sphalerites 353 samples treated under different conditions (Acero et al. 2007; Harmer et al. 2008; Mikhlin et al. 354 2016). However, the reasons why sulfoxy-compounds are not retained on altered sphalerite 
surfaces remains unknown and beyond the scope of the present study. Complementary to Fig. 5,

$356 \mathrm{~Pb} 4 d$ spectrum of the Fig. S5b provided supplementary evidence regarding concomitant galena 357 oxidation in the simulated sphalerite weathering system (i.e., $0.1 \mathrm{M} \mathrm{H}_{2} \mathrm{SO}_{4}$ ), whereby the 358 occurrence of altered concomitant galena was identified to form anglesite-like secondary 359 compounds. The findings presented in Figs. 4 and 5 confirm the clear occurrence of polysulfides 360 (i.e., $\mathrm{S}_{n}{ }^{2-}$ ), as main secondary products, during the simulated weathering of sphalerite; whence a 361 significant galena oxidation was also identified to form anglesite-like secondary compounds on 362 altered galena surfaces associated to the $\mathrm{PbS}-\mathrm{ZnS}$ grain particles system.

364 Fig. 6 shows the intensity vs erosion time profiles obtained during GDOES analysis of the 365 pristine and leached samples to illustrate specific structure-reactivity relationships (i.e., S, Zn, Fe 366 and $\mathrm{Cd}$ chemical behavior). The composition changes with depth (i.e., erosion times). The 367 comparison between intensities of sulfur and Zn profiles for pristine and leached samples indicate 368 a cyclic evolution of sulfur compounds with depletion-enrichment processes (Fig. 6a, i.e., > 6 $369 \mathrm{sec}$ ). Likewise, in Fig. 6a it is observed that the mineral surface (i.e., shorter erosion times) 370 contain high concentrations of sulfur when was treated with $0.1 \mathrm{M} \mathrm{NaOH}$ or $0.1 \mathrm{M} \mathrm{NaNO}_{3}$ 371 solutions. These results confirm what was observed by XPS (Fig. 5). It was observed that the 372 lowest intensity of Fe corresponds to the mineral treated with $0.1 \mathrm{M} \mathrm{NaOH}$ solution (Fig. 6c). 373 While the highest intensity of Fe corresponds to the mineral treated with $0.1 \mathrm{M} \mathrm{H}_{2} \mathrm{SO}_{4}$ solution 374 (erosion times greater than $4 \mathrm{sec}$.). Finally, Cd profiles show highest intensity for samples treated 375 with $\mathrm{H}_{2} \mathrm{SO}_{4}$ solution while highest depletion is identified for samples treated with $\mathrm{NaNO}_{3}$ after 7 376 sec (Fig. 6d). Note that GDOES analysis has been typically used to characterize the variation in 377 the composition of metals in the layer of alteration products, as a function of the thickness in the 378 structure of materials (i.e., wt. \% vs $\mu \mathrm{m}$ ) (Yang et al., 2018). However, when the occurrence of 
alteration products layer does not present a homogeneous distribution pattern on surfaces, the use

380

381

382

383

384

385

386

387 of intensity profiles vs. erosion time is then used, which allows identifying at which point of the product structure occurs the greatest proportion of metals (Hoffmann et al. 2003). The findings presented in Fig. 6 suggest the occurrence of an inhomogeneous distributed layer of secondary products (i.e., $\mathrm{S}_{n}{ }^{2-}$ ) on altered sphalerite surfaces, whence the presence of non-stoichiometric metal-deficient layers $\left(\mathrm{Zn}_{1-\mathrm{x}} \mathrm{S}_{1-\mathrm{y}}\right.$-like structures) involves dynamic variations of sulfur, $\mathrm{Zn}, \mathrm{Fe}$ and Cd elements to exhibit specific structure-activity relationships, in agreement with previous results (Figs. 2 to 5, Tables 1, S1, S2).

\subsection{Electrochemical assessment}

Voltammetry is commonly used to define regions of potential where the current flows as a response of certain electrochemical process (i.e., sphalerite interface/electrolyte solution). In the present study, this technique was utilized to analyze particularly the oxidation processes of pristine $\mathrm{FeZnS}$ and $\mathrm{PbS}-\mathrm{ZnS}$ samples under conditions used in the simulated weathering process (See Section 2.3). This approach was also performed to elucidate the energetics and the reactions of sphalerite surfaces after $24 \mathrm{~h}$ of leaching. Altered $\mathrm{PbS}-\mathrm{ZnS}$ samples were mineralogically characterized in "Section 3.3"; however, the energetics and kinetics processes were not properly assessed with this approach, whence an electrochemical evaluation was carried out (i.e., oxidation potential). Note that a comprehensive electrochemical assessment comparing CPE$\mathrm{PbS}-\mathrm{ZnS}$ and CPE-FeZnS samples has not been reported to our current state of knowledge; therefore, the experimental evidences provided here allowed a broaden understanding of the sphalerite weathering and mineral activity under simulated weathering conditions. 
Fig. 7 shows cyclic voltammograms conducted on CPE-PbS-ZnS (curves identified as i) and

403 CPE-FeZnS samples (curves identified as ii) in $0.1 \mathrm{M} \mathrm{NaOH}$ (Fig. 7a), $0.1 \mathrm{M} \mathrm{NaNO}_{3}$ (Fig. 7b), $4040.1 \mathrm{M} \mathrm{HClO}_{4}$ (Fig. 7c) or $0.1 \mathrm{M} \mathrm{H}_{2} \mathrm{SO}_{4}$ (Fig. 7d) solutions. The CPE with $100 \%$ graphite, which 405 is inert to sphalerite and electrolytes composed of conductive carbon phase, was also included for 406 comparison purposes (curves identified as iii). A complementary comparison between positive 407 scans (black curves, curves identified as i) and negative scans (red curves, curves identified as ii) 408 was included for CPE-marmatite-like systems (Figs. S6 and S7). According to Fig. 7 and the 409 corresponding $\mathrm{E}_{\lambda \pm}$ study (data not shown), the sphalerite oxidation is complex, progressive and 410 several stages can be elucidated from these voltammograms. Three main oxidation processes (O1 411 from $\mathrm{OCP}_{i=0}$ to $\sim 0.5 \mathrm{~V}, \mathrm{O} 2$ from $\sim 0.5$ to $\sim 0.75 \mathrm{~V}$, and after $\sim 0.75 \mathrm{~V}$ ) are defined during the 412 positive scans of the PbS-ZnS sample in $0.1 \mathrm{M} \mathrm{NaOH}$ (Fig. 7a, curve i) and $0.1 \mathrm{M} \mathrm{NaNO}_{3}$ (Fig. $4137 \mathrm{~b}$, curve i) conditions. In contrast, a slow process followed by single-enhanced oxidation was 414 clearly observed in $0.1 \mathrm{M} \mathrm{HClO}_{4}$ (Fig. 7c, curve i) and $0.1 \mathrm{M} \mathrm{H}_{2} \mathrm{SO}_{4}$ (Fig. 7d, curve i) conditions 415 (O2 and O3). The first $\mathrm{O} 1$ and $\mathrm{O} 2$ processes for the PbS-ZnS sample (mainly treated with $\mathrm{NaOH}$ 416 and $\mathrm{NaNO}_{3}$ ) can be associated with the first (incipient) weathering process of the concomitant 417 galena impurity to form Pb-bearing secondary compounds (Wang et al. 2021). This establishes 418 mineral oxidation due to galvanic interaction processes with sphalerite leading to the potential 419 formation of the anglesite-like compound (i.e., $0.1 \mathrm{M} \mathrm{H}_{2} \mathrm{SO}_{4}$ and other conditions, Fig. S4) 420 (Urbano et al. 2007; Wang et al. 2021), thus, indicating that the highest degree of sphalerite 421 weathering occurs long-place term under environmental weathering conditions. Regarding the 422 oxidative processes of the FeZnS sample, a very slow oxidation process (O1, from $\mathrm{OCP}_{i=0}$ to $4230.75 \mathrm{~V} / \mathrm{SCE}$ ) which was followed by progressive and highlighted oxidation process was in 424 general observed under all tested conditions (involving potential region of $\mathrm{O} 2$ and $\mathrm{O} 3$, after 0.75 425 V/SCE, Figs. 7, S6 and S7). While the FeZnS oxidation in 0.1 M NaOH solution was more prone 
to increase mineral oxidation regarding the other tested conditions (Fig. S6), indicating the

427 release of soluble $\mathrm{Zn}$ in alkaline weathering conditions (i.e., $\mathrm{Zn}(\mathrm{OH})_{3}{ }^{-}$, Fig. S14).

429 All the findings presented here were disclosed in Figs. 7, S6 and S7 exhibiting general 430 comparison to illustrate differences regarding the weathering processes of the $\mathrm{PbS}-\mathrm{ZnS}$ and 431 FeZnS samples, according to the following order of mineral activity in systems: $\mathrm{NaOH}>\mathrm{NaNO}_{3}>$ $432 \mathrm{HClO}_{4}>\mathrm{H}_{2} \mathrm{SO}_{4}$. Oxidation processes are in general lower for $\mathrm{PbS}-\mathrm{ZnS}$ and FeZnS samples 433 including at least two major stages (i.e., O1 and O2-O3) to constitute sluggish oxidation 434 processes, in agreement with mineralogical observations (Figs. 2 to 6) and chemical evolution of 435 leachates (Fig. 1). Regarding the reduction processes, some of them are identified during the 436 reversed positive scans on voltammograms (Figs. 7, S6 and S7), which were mainly associated 437 with the reduction of the secondary phases generated during oxidation of the samples as well as 438 the intrinsic reduction of the pristine mineral structures as described elsewhere (Ahlberg and 439 Ásbjörnsson 1994; Chen and Yoon 2000; Urbano et al. 2007; Wang et al. 2013; Karimi et al. 440 2017). Note that literature regarding the electrochemical oxidation of sphalerite samples is not 441 recent but scarce and sparsed (Choi et al. 1993; Ahlberg and Ásbjörnsson 1994; Chen and Yoon 442 2000; Srinivasan and Iver 2000; Da Silva 2004). The electrochemical behavior of the sphalerite 443 samples presented in Fig. 7 shows oxidation processes for FeZnS and PbS-ZnS samples under 444 tested conditions but involving comprehensive and unprecedented comparisons. While galena 445 oxidation is predominant for the $\mathrm{PbS}-\mathrm{ZnS}$ samples oxidation up to potentials close to $0.8 \mathrm{~V} / \mathrm{SCE}$ 446 revealing that weathering process of this sample occurs with several stages. Major findings 447 provided in Fig. 7 also aim to complement understanding of the environmental sphalerite 448 oxidation since diversity of impurities or varied Fe contain modify mineral activity or oxidation 449 capacity with potential release of Zn (Babedi et al. 2021). 
The different energetic and kinetic stages of the sphalerite oxidation trends were further evaluated

451 by chronoamperometry and chronopotentiometry under all tested conditions. Figs. S8 to S10

452 show obtained curves ( $\mathrm{I}_{s}$ vs. E) describing electrochemical behavior of the PbS-ZnS and FeZnS

453 samples, complimentary to Figs. 7 and S6. According to Fig. S8, the occurrence of at least two

454 main oxidative complex mechanisms are identified under all tested conditions, in agreement with

455 CV study. Additionally, Figs. S9 and S10 indicated a not-time dependent oxidation for PbS-ZnS

456 and $\mathrm{FeZnS}$ treated with $0.1 \mathrm{M} \mathrm{NaNO}_{3}$ or $0.1 \mathrm{M} \mathrm{HClO}_{4}$ solution. These curves suggested a rapid

457 increment of the oxidative current whence intensity of the mineral weathering depended mainly

458 on the potential reached in systems $\left(0.8>\mathrm{E}_{a}>0.6 \mathrm{~V} / \mathrm{SCE}\right)$. In contrast, $\mathrm{I}_{s}$ vs $\mathrm{E}$ curves revealed

459 significant time-dependent oxidation for the $\mathrm{PbS}-\mathrm{ZnS}$ and FeZnS sample treated with $0.1 \mathrm{M}$

$460 \mathrm{NaOH}$ or $0.1 \mathrm{M} \mathrm{H}_{2} \mathrm{SO}_{4}$ solution $\left(\mathrm{E}_{a}>0.8 \mathrm{~V} / \mathrm{SCE}\right)$. The dependence of time in oxidation processes

461 would imply that once certain overpotentials have been reached during weathering conditions

462 (i.e., $\mathrm{E}_{a}>0.8 \mathrm{~V} / \mathrm{SCE}$ ), there would be a significant oxidation where the release of $\mathrm{Zn}$ and sulfur

463 soluble species occur leading to the progressive accumulation of secondary compounds on 464 surfaces promoting progressive (potential) mineral passivation (Figs. S9 and S10). All these

465 findings generally explain why the oxidation of sphalerite is sluggish process, whereby there is a 466 need to establish important overpotentials (i.e., energetic conditions) for a significant weathering 467 process to occur, in agreement with Fig. 1 and mineralogical characterizations (Figs. 2 to 4, S5 to 468 S7).

470 Tafel analysis is typically used to quantify the kinetics of the rate-determining steps in systems, 471 since it estimates the voltage that needs to be applied to increase the current by one order of 472 magnitude. Tafel plots can then be then used to better understand the kinetics behavior of the $473 \mathrm{PbS}-\mathrm{ZnS}$ samples and FeZnS weathering under all tested conditions. Note that most studies using 
474 Tafel plots for materials are based on obtaining parameters such as the exchange current density

475 since this parameter is drawn on well-defined reactions and mechanisms (Meng et al. 2019;

476 Zhang et al. 2020); however, such approach requires a precise reaction mechanism for a given

477 potential region, which is very difficult to achieve in the case of the MS oxidation due to

478 imprecision of defining exact reactions occurring during oxidation. An additional approach that

479 does not depend on the exchange current density is then required for the present assessment, for

480 instance, using the potential of corrosion ( $\left.E_{\text {corr }}\right)$ or oxidation, which can be easily determined 481 during the electrochemical oxidation of sphalerite samples (Figs. 7 and S6). In this study, a 482 modified Buttler-Volmer equation in terms of $\mathrm{E}_{\mathrm{corr}}$ was used for obtaining electrochemical 483 kinetics parameters (Figs. 8, S11 to S13, Eqs. 1 to 3, Table 3):

484

485

$i_{0}=n F k_{f} * C_{R}^{b} \exp \left(\frac{\alpha_{A} n F}{R T} E\right) \quad \alpha_{A}=1-\alpha_{C}$

486

487

$i_{0}=n F k_{f} * C_{R}^{b} \exp \left(\frac{\alpha_{A} n F}{R T} E_{e q}\right)=-n F k_{b} * C_{O}^{b} \exp \left(\frac{-\alpha_{C} n F}{R T} E_{e q}\right)$

488

489

$I=n F k_{f} * C_{R}^{b} \exp \left(\frac{\alpha_{A} n F}{R T} E\right)-n F k_{b} * C_{O}^{b} \exp \left(\frac{-\alpha_{C} n F}{R T} E\right)$

490

491 Where $\boldsymbol{i}_{\mathbf{0}}$ is exchange current, $\boldsymbol{\eta}$, overpotential, $\boldsymbol{\alpha}_{\boldsymbol{A}, \boldsymbol{C}}$, transfer charge coefficients for anodic or

492 cathodic branches, $\mathbf{n}$, transfered electron number for the limitant step, $\boldsymbol{C}_{\boldsymbol{R}}^{\boldsymbol{b}}$, bulk concentration of 493 reduced species, $\boldsymbol{C}_{\boldsymbol{o}}^{\boldsymbol{b}}$, bulk concentration of oxidized species, $\boldsymbol{k}_{\boldsymbol{f}}$, rate constant for oxidation, $\boldsymbol{F}$, 494 Faraday number and $\boldsymbol{k}_{\boldsymbol{b}}$, rate constant for reduction. The details and further considerations for the 495 present approach are given in ESM section (Figs. S11 to S13). Fig. 8 confirms the complex 496 nature of the oxidation processes (i.e., anodic branches) in all tested solutions, whereby reduction 


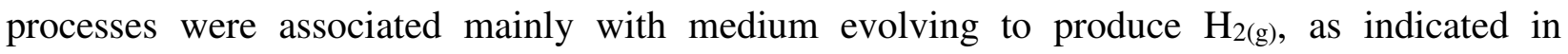

498 literature (Ahlberg and Ásbjörnsson 1994; Karimi et al. 2017, Karimi et al. 2018). As observed in

499 Table 3, the least negative $\mathrm{E}_{\text {corr }}$ is obtained for $\mathrm{NaOH}$ followed very close by $\mathrm{HClO}_{4}$ and $\mathrm{NaNO}_{3}$,

500 and after $\mathrm{H}_{2} \mathrm{SO}_{4}$. This indicates that less electric work (energetics) needs to be applied to oxidize

501 the PbS-ZnS and FeZnS samples in $0.1 \mathrm{M} \mathrm{NaOH}$, while the medium with a lower oxidation is

$502 \mathrm{H}_{2} \mathrm{SO}_{4}$. This result confirms the evidence above described in the Cyclic Voltammetry analysis

503 (Fig. 7), Chronoamperometry (Figs. S9 and S10) and Chronopotentiometry (Figs. S8). The fact

504 that $\mathrm{PbS}-\mathrm{ZnS}$ and $\mathrm{FeZnS}$ present a higher activity in $\mathrm{NaOH}$ is also corroborated in the rate

505 constants for oxidation (Table 3) which are three and one order of magnitude, respectively,

506 higher compared to the other solutions. Likewise, the $\boldsymbol{k}_{\boldsymbol{f}} \boldsymbol{C}_{\boldsymbol{R}}^{\boldsymbol{b}}$ value in general reveals that FeZnS

507 oxidation is slightly more prone to occur than the $\mathrm{PbS}-\mathrm{ZnS}$ sample; although both processes are

508 slow as previously described (i.e., Tafel slopes located between 100 and $150 \mathrm{mV} \mathrm{dec}^{-1}$ ).

509 Accordingly, it was also observed that the oxidation of the PbS-ZnS sample proceeded first than

510 the FeZnS sample in all tested systems, particularly under the $0.1 \mathrm{M} \mathrm{NaOH}$ conditions, which

511 was associated with enhanced sphalerite oxidation due to galvanic interactions with galena

512 (Urbano et al. 2007; Srinivasan and Iver 2000; Karimi et al. 2018; Table 1, Fig. 5). The Tafel

513 plots are found to vary from 0 to $1.2 \mathrm{~V} / \mathrm{SCE}$. The form of Tafel plots at high potentials has found

514 to vary depending on the alteration degree and surface composition (Ahlberg and Ásbjörnsson,

515 1994; Meng et al. 2019; Schippers et al. 2019). Accordingly, Tafel plots ranging from $\sim 0.1$ to

$516 \sim 0.8 \mathrm{~V} / \mathrm{SCE}$ described most significant stages for mineral weathering whereby the most possible

517 explanation is the progressive surface modifications to evolution of inhomogeneous polysulfide

518 compounds layers (and eventually $\mathrm{S}^{0}$ compounds in the FeZnS sample) and the development of

519 additional secondary compounds (i.e., anglesite $\left(\mathrm{PbSO}_{4}\right)$-like due) to galvanic interactions with

520 galena in the PbS-ZnS sample (Figs. 4, S4 and S5b), in agreement with $\mathrm{E}_{\text {corr }}$ and $\mathrm{K}_{f}$ constants 
521 (Table 3). The shift in the Tafel curves after $\sim 0.8 \mathrm{~V} / \mathrm{SCE}$ was then attributed to different charge

522 transfer kinetics of the enhanced sphalerite dissolution to form sulfoxy-compounds (i.e., $\mathrm{Zn}^{2+}$,

$523 \mathrm{~S}_{2} \mathrm{O}_{3}{ }^{2-}, \mathrm{SO}_{4}{ }^{2-}$, in agreement with chronopotentiometric and chronoamperometric assessments

524 describing at least two major stages for the weathering processes (Figs. S6 to S12, Table 3).

\section{$526 \quad 3.5$. Reactivity assessment}

527 The evolution of electrochemical reactivity of altered mineral surfaces can be used to predict 528 changes of the oxidation capacity of the $\mathrm{PbS}-\mathrm{ZnS}$ and FeZnS samples, as a function of the 529 secondary compounds development (Cruz et al. 2001). The progress of secondary compounds 530 was achieved by applying anodic pulses $\left(\mathrm{E}_{a}=1.2 \mathrm{~V} / \mathrm{SCE}\right)$ during 1 and/or $2 \mathrm{~h}$ using the same 531 electrolytes for characterization purposes (See section 2.2). According to Fig. 9, the voltammetric 532 behavior of $\mathrm{PbS}-\mathrm{ZnS}$ and $\mathrm{FeZnS}$ samples are clearly affected by the simulated weathering 533 process. In general, FeZnS samples showed the progressive surface passivation most probably 534 due to secondary compounds accumulation (i.e., at high potentials, Fig. 9a to 9d). In contrast, the 535 mineral activity of the $\mathrm{PbS}-\mathrm{ZnS}$ samples indicated alternating passivation-oxidation stages, in all 536 tested solutions, whence secondary compounds seems to promote a delayed surface passivation 537 regarding FeZnS samples (Fig. 9a' to 9d'). These results agree with the leachates analysis, 538 mineralogical characterizations and electrochemical assessments of pristine PbS-ZnS and FeZnS 539 samples (Figs. 1, 4, 5 and S4), and indicate that the sphalerite weathering follows a mechanism 540 similar to that of sphalerite electrochemical oxidation under simulated weathering conditions. 
545 The chemical analysis of leachates generated during simulated sphalerite (i.e., $\mathrm{PbS}-\mathrm{ZnS}$ ) 546 weathering processes indicated limited $\mathrm{Zn}, \mathrm{Fe}, \mathrm{Cd}$ and sulfates ions dissolution (Fig. 1). 547 Additionally, mineralogical analysis of these mineral samples confirmed that the polysulfides 548 (i.e., $\mathrm{S}_{n}{ }^{2-}$ ) are the main sulfur compounds during weathering processes for all tested conditions. 549 The progressive enrichment of altered samples with $\mathrm{S}_{n}{ }^{2-} / \mathrm{S}^{0}$ compounds can also occur for a more 550 extend weathering process (Fig. S5a). It was not identified Zn-bearing secondary compounds

551 (i.e., $\mathrm{ZnSO}_{4}, \mathrm{Zn}(\mathrm{OH})_{2}$ ) on altered mineral surfaces (according to XPS study), suggesting a rapid 552 diffusion of just $\mathrm{Zn}^{2+}$ release into bulk-solution systems (i.e., stirring conditions). These findings 553 suggested that solid secondary compounds are bare during environmental weathering of the low$554 \mathrm{Fe}$ and $\mathrm{Pb}$-bearing sphalerite samples (i.e., $\mathrm{PbS}-\mathrm{ZnS}$ ) to form mainly soluble sulfur and $\mathrm{Zn}$ 555 compounds (i.e., $\mathrm{Zn}^{2+}, \mathrm{SO}_{4}{ }^{2-}$ ) in the systems. This same observation is possible based on 556 extensive electrochemical assessments (i.e., Figs. S8 to S12, 7 to 9) for the marmatite-like 557 samples (i.e., FeZnS), and according to literature illustrating the progressive surface $\mathrm{S}^{0} / \mathrm{S}_{n}{ }^{2-}$ 558 enrichment after 24 of leaching in acidic or circumneutral solutions (Acero et al. 2007; Harmer et 559 al. 2008; Schippers et al. 2021; Babedi et al. 2021). Therefore, the results presented in this work 560 complement the existing reports for the oxidation of Fe-rich sphalerite samples at short intervals 561 of alteration, particularly when sphalerite weathering occurs in mining waste environments (Bao 562 et al. 2021).

564 On the basis of the experimental evidence presented here, equilibrium data from literature (i.e., 565 Bobeck and Su, 1985) and/or equilibrium data calculated in Fig. S14, the following weathering 566 mechanisms are suggested to describe major sphalerite oxidation process (i.e., $\mathrm{PbS}-\mathrm{ZnS}$ and 567 FeZnS samples) under most typical weathering environments (i.e., $\mathrm{NaOH}, \mathrm{NaNO}_{3}, \mathrm{HClO}_{4}$ or 
$568 \mathrm{H}_{2} \mathrm{SO}_{4}$ ). The initial stage of the sphalerite oxidation seems to be the same under all tested 569 conditions, regarding sulfur bulk-species (i.e., $\mathrm{S}^{2-}$ ), which is attributed to the bare capacity of the $570 \mathrm{PbS}-\mathrm{ZnS}$ sample to oxidize, thus involving sluggish weathering to form non-stoichiometric 571 metal-deficient-like layers mainly composed of polysulfides (i.e., $\mathrm{Zn}_{1-\mathrm{x}} \mathrm{S}$-like structures); these 572 mechanisms also involve bare $\mathrm{Zn}^{2+}$ release, according to the next simplified reactions for acidic 573 (Eq. 4), circumneutral (Eq. 5) and alkaline (Eq. 6) conditions:

$575 \quad \mathrm{ZnS}_{(\mathrm{s})} \rightarrow \mathrm{Zn}_{1-\mathrm{x}} \mathrm{S}_{(\mathrm{s})}+\mathrm{xZn}^{2+}+2 \mathrm{xe}^{-}$

576

577

$$
\mathrm{ZnS}_{(\mathrm{s})}+\mathrm{xH}_{2} \mathrm{O} \rightarrow \mathrm{Zn}_{1-\mathrm{x}} \mathrm{S}_{(\mathrm{s})}+\mathrm{xZnOH}^{+}+\mathrm{xH}^{+}+2 \mathrm{xe}^{-}
$$

If $\mathrm{Fe}$ content is considered, an alternative reaction scheme could then involve the $\mathrm{Fe}^{2+}$ release

582 from the FeZnS structure (Babedi et al. 2021; Crundwell 2021), in agreement with the following 583 simplified general process:

$\mathrm{FeZnS}_{(\mathrm{s})}+(\mathrm{x}+\mathrm{y}) \mathrm{H}_{2} \mathrm{O} \rightarrow \mathrm{Fe}_{1-\mathrm{y}} \mathrm{Zn}_{1-\mathrm{x}} \mathrm{S}_{(\mathrm{s})}+\mathrm{xZn}(\mathrm{OH})^{+}+\mathrm{yFe}^{2+}+(\mathrm{x}+2 \mathrm{y}) \mathrm{H}^{+}+2(\mathrm{x}+2 \mathrm{y}) \mathrm{e}^{-}$

587 These weathering reactions suggest specific sphalerite activity, despite of weathering reactions 588 occurring in typical acidic $\left(0.1 \mathrm{M} \mathrm{H}_{2} \mathrm{SO}_{4}\right)$, acidic-saline $\left(0.1 \mathrm{M} \mathrm{HClO}_{4}\right)$, circumneutral $(0.1 \mathrm{M}$

$\left.589 \mathrm{NaNO}_{3}\right)$ and alkaline $(0.1 \mathrm{M} \mathrm{NaOH})$ saturated conditions. However, $\mathrm{pH}$, ORP, sulfates and $\mathrm{Zn}$ 
measurements along with AFM (Fig. 2) and SEM-EDS (Figs. 3 and S3) studies highlight general

591 sluggish oxidation mechanisms, in agreement with Eqs. 4 to 6. Additionally, Raman spectroscopy 592 and XPS indicate the formation of i.e., $\mathrm{Zn}_{1-\mathrm{x}} \mathrm{S}_{1-\mathrm{y}(\mathrm{s})}$ secondary compounds for later stages of 593 mineral weathering involving inhomogeneous distribution of secondary compounds on altered 594 surfaces (Figs. 5 and 6). Concomitant galena weathering was also identified on free-altered 595 galena particles associated with the $\mathrm{PbS}-\mathrm{ZnS}$ grain particles system (i.e., $0.1 \mathrm{M} \mathrm{H}_{2} \mathrm{SO}_{4}$ 596 conditions) to form an anglesite $\left(\mathrm{PbSO}_{4}\right)$-like compound (Figs. $\mathrm{S} 4$ and $\mathrm{S} 5 \mathrm{~b}$ ). Considering the 597 potential formation of this compound due to galvanic interaction between galena and the 598 sphalerite sample (Urbano et al. 2007; Srinivasan and Iver 2000); the following reaction scheme 599 is also suggested to accompaniment of Eqs. 4 to 6 for the case of the PbS-ZnS sample:

600

601

$\mathrm{PbS}_{(\mathrm{s})}+2 \mathrm{H}_{2} \mathrm{O}+\mathrm{O}_{2} \rightarrow \mathrm{PbSO}_{4(\mathrm{~s})}+4 \mathrm{H}^{+}+4 \mathrm{e}^{-}$

602

The effect of the concomitant galena oxidation is strongly suggested by the literature (Urbano et 604 al. 2007; Srinivasan and Iver 2000; Karimi et al. 2018), and our Raman study (Fig. S4). 605 Accordingly, this oxidative behavior is determined by electrochemical assessment of the PbS$606 \mathrm{ZnS}$ sample in $0.1 \mathrm{M} \mathrm{H}_{2} \mathrm{SO}_{4}$ solution helping to disclose stages associated with this synergistic 607 weathering mechanism (Figs. S4 and S5b). Additionally, the corresponding depletion of Fe, Zn 608 and $\mathrm{Cd}$ in the $\mathrm{PbS}-\mathrm{ZnS}$ samples (Figs. 1 and 6), together with varied formation of 609 inhomogeneous secondary compounds, leaded to the progressive passivation of the samples, as 610 indicated by Figs. 7, 9, and S6, enhancing the production of mainly soluble but also surface 611 compounds (i.e., $\mathrm{SO}_{4}{ }^{2-}, \mathrm{S}_{2} \mathrm{O}_{3}{ }^{2-}, \mathrm{Zn}^{2+}$ ), according to the next simplified global scheme: 
615 This same weathering process can be suggested for the case of the FeZnS sample, where 616 electrochemical studies (Figs. 7, S6 to S12) indicated the progressive enrichment of sulfur 617 compounds $\left(\mathrm{S}_{n}{ }^{2-} / \mathrm{S}^{0}\right)$ through a two main stage oxidative process, even for the PbS-ZnS sample 618 (Figs. 7, S6 to S12). The progressive enrichment of $\mathrm{S}_{n}{ }^{2-} / \mathrm{S}^{0}$ compounds is well documented in 619 elsewhere for a long $\mathrm{pH}$ range describing oxidation of Fe-rich sphalerite specimens (Acero et al.

620 2007; Harmer et al. 2008; Schippers et al. 2021; Babedi et al. 2021). The continuous bare 621 production and oxidation of polysulfides (and likely $\mathrm{S}^{0}$ ) to form sulfoxy-compounds (i.e., $\mathrm{S}_{2} \mathrm{O}_{3}{ }^{2-}$, $\left.622 \mathrm{SO}_{4}{ }^{2-}\right)$ allows equilibrium of mineral activity, which occur indirectly after transpassive oxidation 623 of PbS-ZnS (i.e., anglesite-like compound) and directly oxidation of the FeZnS sample (i.e., after 624 formation and accumulation of $\mathrm{S}_{n}{ }^{2-} / \mathrm{S}^{0}$ compounds), according to the following scheme:

$\mathrm{S}^{0}+2 \mathrm{zH}_{2} \mathrm{O}+\mathrm{zO}_{2}=\mathrm{zSO}_{4}^{2-}+4 \mathrm{zH}^{+}+2 \mathrm{ze}^{-}$

628 Complex kinetic mechanisms were enhanced for the $\mathrm{PbS}-\mathrm{ZnS}$ and FeZnS samples in $0.1 \mathrm{M}$ $629 \mathrm{NaOH}$ solution, which suggested that sphalerite weathering was favored in alkaline conditions 630 (Figs. 7, 8, S6 to S12); however, the rest of the tested systems revealed similar kinetic processes 631 among them, even under acidic conditions of the $0.1 \mathrm{M} \mathrm{H}_{2} \mathrm{SO}_{4}$ system (Fig. 8). This fact was 632 associated with the enhanced release of $\mathrm{Zn}$ to bulk-system (Fig. 1d), avoiding more accumulation 633 of sub-micro sized secondary compounds regarding the other tested systems (Figs. 2 and 3, Table $6341)$. 
636 The pollution process for $\mathrm{Zn}$ release in soils has been studied under different climate and 637 weathering conditions (i.e., alkaline or acidic soils) whereby $\mathrm{Zn}$ (and other heavy metals) 638 behavior was associated to the weathering of primary Zn-bearing phases in regions affected by 639 mining waste spillage with significant impacts to the environment (i.e., FeZnS, PbS-ZnS, Razo et 640 al. 2004; Jaqcuat et al. 2008; Navarro et al. 2008; Jalali and Khanlari 2008; Jalali and Moradi 641 2013). Most of these studies were conducted considering sphalerite weathering in the context of 642 physicochemical reactions occurring in mining waste environments with significant production of 643 acid solutions (Bao et al. 2021). The results presented in the present work improve the scientific 644 perspective of the reactions and stages of alteration of different forms of sphalerite, and offer 645 kinetic calculations with an adequate methodological approach, helping to better elucidate the 646 interfacial phenomena and providing a thorough assessment of the reaction mechanisms 647 controlling the release of $\mathrm{Zn}$ from mine wastes and their mobilization and attenuation in 648 environment. To this context, there are also scenarios where the study of the alteration of the 649 sphalerite is unprecedented, as is the case of the alteration of sphalerite in simulated calcareous 650 (alkaline) soils conditions. This information is relevant since prospective findings helps to better 651 understand the impact and mobility processes of $\mathrm{Zn}$, accounting for relevant aspects of the 652 stability and activity of sphalerite and the corresponding secondary compounds in such 653 conditions (Navarro et al. 2008; Álvares-Ayuso et al. 2013), which can be helpful for further 654 establishment of legal and efficient designing of mining practices and for urban planning, among 655 others, in benefit of environmental and health risk issues. 


\section{Conclusions}

661

662

663

664

665

A comphrensive methodology of chemical analysis of leachates along with mineralogical and electrochemical assessments were carried out to describe the main weathering process of sphalerite under simulated environmental conditions, revealing the following findings:

(1) The sphalerite weathering process is in general sluggish involving the occurrence of minor, sub-micro sized and non-homogeneously distributed polysulfides compounds on altered surfaces.

(2) The weathering processes occur mainly with the modification of the surface-bulk structure (i.e., surface-activity relationships), to form mineral rimmed particles with different degree of alteration under all tested conditions. The presence of anglesite $\left(\mathrm{PbSO}_{4}\right)$-like compound is identified on galena free-particles, revealing the concomitant weathering of galena, which is associated with the $\mathrm{PbS}-\mathrm{ZnS}$ system; this result supports extra experimental evidence regarding the formation of secondary compounds on the main sulfide impurity of sphalerite samples under simulated environmental weathering conditions. Additionally, the weathering of sphalerite leaded to the main production of soluble secondary phases (i.e., $\mathrm{ZnOH}^{+}, \mathrm{S}_{2} \mathrm{O}_{3}{ }^{2-}, \mathrm{SO}_{4}{ }^{2-}$ ) while not $\mathrm{Zn}$-bearing secondary compounds is identified on altered surfaces.

(3) The kinetic sphalerite oxidation process is enhanced in $0.1 \mathrm{M} \mathrm{NaOH}$ conditions, while this oxidation is similar for the rest of tested conditions involving the following activity order: $\mathrm{NaOH}>\mathrm{NaNO}_{3}>\mathrm{HClO}_{4}>\mathrm{H}_{2} \mathrm{SO}_{4}$. The electrochemical oxidation processes 
Not applicable

\section{Ethical Approval}

includes two main stages at least, where the establishment of the corresponding specific structure-activity relationships are illustrated with spectroscopic techniques (GDOES, Raman, XPS). Additionally, a clear weathering trend involving the progressive passivation of the FeZnS samples is revealed during mineral activity evolution assessment. While an alternated passive to transpassive oxidation stage is then observed for the $\mathrm{PbS}-\mathrm{ZnS}$ sample during mineral activity evolution.

\section{Acknowledgments}

This work has been financially supported by the Mexican National Science and Technology Council (CONACYT), project number 5604, and the Science and Technology Council of the State of Durango (COCYTED), Institutional Support and Funding Research Academic and Industry Program 2019-01, project number 34, and the PROFOCIES-UJED 2020 program. The authors appreciate the contributions from Ing. Erasmo Mata-Martínez (IG-UASLP) for sphalerite samples obtaining, conditioning and preparation for mineralogical analyses.

\section{Statements and declarations}

\section{Competing interests}

Authors declare no competing or financial interest 
707 Fabiola S. Sosa-Rodríguez and René H. Lara contributed as follows: Methodology, Resources, 708 Funding, Investigation and Conceptualization, Writing and Review Analysis, Project 709 administration. Jorge Vazquez-Arenas: Resources, Funding, Formal Analysis, Software and 710 Validation, Writing and Review Analysis. Patricia Ponce Peña, Antonio Aragón-Piña, 711 Martine Mallet, Gabriel Trejo-Córdova, Diola M. Núñez-Ramírez and Miguel A. Escobedo712 Bretado: Methodology, Investigation, Supervising and Formal Analysis

714 Consent to participate

715 Not applicable

\section{Consent to publish}

718 All authors consent publication of the present submission

\section{Availability of data and materials}

721 The data and materials report in the present submission are available on request 
728 Acero P, Cama J, Ayora C (2007) Sphalerite dissolution kinetics in acidic environment. Appl

729 Geochem 22: 1872-1883. https://doi.org/10.1016/j.apgeochem.2007.03.051

730 Ahlberg E, Ásbjörnsson J (1994) Carbon paste electrodes in mineral processing: an 731 electrochemical study of sphalerite. Hydrometallurgy 36: 19-37. https://doi.org/10.1016/0304$732 \quad 386 X(94) 90039-6$

733 Álvarez-Ayuso E, Otones V, Murciego A, García-Sánchez A, Santa Regina I (2013) Zinc, 734 cadmium and thallium distribution in soils and plants of an area impacted by sphalerite-bearing 735 mine wastes. Geoderma 207: 25-34. https://doi.org/10.1016/j.geoderma.2013.04.033

736 Babedi L, Tadie M, Neethling P, Von der Heyden BP (2021) A fundamental assessment of the 737 impacts of cation $(\mathrm{Cd}, \mathrm{Co}, \mathrm{Fe})$ substitution on the molecular chemistry and surface reactivity of 738 sphalerite. Miner Engineer. https://doi.org/10.1016/j.mineng.2020.106695

739 Bao Z, Al T, Bain J, Shrimpton HK, Finfrock Y Z, Ptacek CJ, Blowes DW (2021) Sphalerite 740 weathering and controls on $\mathrm{Zn}$ and $\mathrm{Cd}$ migration in mine waste rock: An integrated study from 741 the molecular scale to the field scale. Geochim Cosmochim Acta. 742 https://doi.org/10.1016/j.gca.2021.11.007

743 Buzatu A, Buzgar N, Damian G, Vasilache V, Apopei AI (2013) The determination of the Fe 744 content in natural sphalerites by means of Raman spectroscopy. Vib Spectrosc 68: 220-224. 745 https://doi.org/10.1016/j.vibspec.2013.08.007

746 Bobeck G, Su H (1985) The kinetics of dissolution of sphalerite in ferric chloride solution. 747 Metallurg Trans B, 16: 413-424. https://link.springer.com/content/pdf/10.1007/BF02654839.pdf 
749 Chen Z, Yoon RH (2000) Electrochemistry of copper activation of sphalerite at pH 9.2. Int J

750 Miner Process 58: 57-66. https://doi.org/10.1016/S0301-7516(99)00047-2

751 Chen A, Zhao Z, Jia X, Long S, Huo G, Chen X (2009) Alkaline leaching Zn and its concomitant

752 metals from refractory hemimorphite zinc oxide ore. Hydrometallurgy 97: 228-232.

753 https://doi.org/10.1016/j.hydromet.2009.01.005

754 Chen Y, Liang W, Li Y, Wu Y, Chen Y, Xiao W, Li H (2019) Modification, application and 755 reaction mechanisms of nano-sized iron sulfide particles for pollutant removal from soil and 756 water: A review. Chem Engineer J 362: 144-159. https://doi.org/10.1016/j.cej.2018.12.175

757 Choi WK, Torma AE, Ohline RW, Ghali E (1993) Electrochemical aspects of zinc sulphide 758 leaching by Thiobacillus ferrooxidans. Hydrometallurgy 33: 137-152. 759 https://doi.org/10.1016/0304-386X(93)90010-B

760 Crundwell FK (2021) The impact of light on the rate and mechanism of dissolution and leaching 761 of natural iron-containing sphalerite, $(\mathrm{Zn}, \quad \mathrm{Fe}) \quad \mathrm{S} . \quad$ Miner $\quad$ Engineer. 762 https://doi.org/10.1016/j.mineng.2020.106702

763 Cruz R, Mendez BA, Monroy M, González I (2001) Cyclic voltammetry applied to evaluate 764 reactivity in sulfide mining residues. Appl Geochem 16: 1631-1640. 765 https://doi.org/10.1016/S0883-2927(01)00035-X

766 Da Silva G, Lastra MR, Budden JR (2003) Electrochemical passivation of sphalerite during 767 bacterial oxidation in the presence of galena. Miner Engineer 16: 199-203. 768 https://doi.org/10.1016/S0892-6875(03)00010-4

769 Da Silva G (2004) Relative importance of diffusion and reaction control during the bacterial and 770 ferric sulphate leaching of zinc sulphide. Hydrometallurgy 73: 313-324. 771 https://doi.org/10.1016/j.hydromet.2004.07.001 
772 DOF Official Journal of the Federation, 2007. NOM-147-SEMARNAT/SSA1-2004. Vol.

773 DCXLII. 2, pp. 35-96.

774 Eaton AD, Clesceri LS, Greenberg AE (1995) APHA. AWWA, WEF, Standard methods for the 775 examination of water and wastewater. 19th Edn, Washington, DC, USA.

776 Eriksson G (1979) An algorithm for the computation of aqueous multi-component, multiphase 777 equilibria. Anal Chim Acta 112: 375-383. https://doi.org/10.1016/S0003-2670(01)85035-2

778 EPA. SW-846, Test Method 9038: Sulfate (turbidimetric), Hazardous Waste Test Methods, U.S. 779 Environmental Protection Agency U.S, Washington, DC, Sept. 1986, p.1-6.

780 Gamiño-Gutiérrez SP, González-Pérez CI, Gonsebatt ME, Monroy-Fernández MG (2013) 781 Arsenic and lead contamination in urban soils of Villa de la Paz (Mexico) affected by historical 782 mine wastes and its effect on children's health studied by micronucleated exfoliated cells assay. 783 Environ Geochem Health 35: 37-51. https://doi.org/10.1007/s10653-012-9469-8

784 Giudici GD, Voltolini M, Moret M (2002) Microscopic surface processes observed during the 785 oxidative dissolution of sphalerite. Eur J Miner 14: 757-762. https://doi.org/10.1127/0935$786 \quad 1221 / 2002 / 0014-0757$

787 Harmer SL, Mierczynska-Vasilev A, Beattie DA, Shapter JG (2008) The effect of bulk iron 788 concentration and heterogeneities on the copper activation of sphalerite. Miner Engineer 21, 789 1005-1012. https://doi.org/10.1016/j.mineng.2008.02.014

790 Heidel C, Tichomirowa M, Junghans M (2013) Oxygen and sulfur isotope investigations of the 791 oxidation of sulfide mixtures containing pyrite, galena, and sphalerite. Chem Geol 342: 29-43. 792 https://doi.org/10.1016/j.chemgeo.2013.01.016 
793 Hita R, Torrent J (2005) Zinc phytoavailability after remediation in soils contaminated by 794 sphalerite-containing pyritic sludge. Plant Soil 271: 341-350. https://doi.org/10.1007/s11104$795 \quad 004-3505-0$

796 Hoffmann V, Dorka R, Wilken L, Hodoroaba VD, Wetzig K (2003) Present possibilities of thin797 layer analysis by GDOES. Surf Interf Anal 35: 575-582. https://doi.org/10.1002/sia.1575

798 Hofmann T, Schuwirth N (2008) $\mathrm{Zn}$ and $\mathrm{Pb}$ release of sphalerite (ZnS)-bearing mine waste 799 tailings. J Soil Sediment 8: 433-441. https://doi.org/10.1007/s11368-008-0052-y

800 Jacquat O, Voegelin A, Villard A, Marcus MA, Kretzschmar R (2008) Formation of Zn-rich 801 phyllosilicate, Zn-layered double hydroxide and hydrozincite in contaminated calcareous soils. 802 Geochim Cosmochim Acta 72: 5037-5054. https://doi.org/10.1016/j.gca.2008.07.024

803 Jalali M, Khanlari ZV (2008) Effect of aging process on the fractionation of heavy metals in 804 some calcareous soils of Iran. Geoderma 143: 26-40. 805 https://doi.org/10.1016/j.geoderma.2007.10.002

806 Jalali M, Moradi F (2013) Competitive sorption of $\mathrm{Cd}, \mathrm{Cu}, \mathrm{Mn}, \mathrm{Ni}, \mathrm{Pb}$ and $\mathrm{Zn}$ in polluted and 807 unpolluted calcareous soils. Environ Monit Assess 185: 8831-8846. 808 https://doi.org/10.1007/s10661-013-3216-1

809 Karimi S, Ghahreman A, Rashchi F (2018) Kinetics of Fe (III)-Fe (II) redox half-reactions on 810 sphalerite $\quad$ surface $\quad$ Electrochim $\quad$ Acta $\quad$ 281: 811 https://doi.org/10.1016/j.electacta.2018.05.132

812 Karimi S, Ghahreman A, Rashchi F, Moghaddam J (2017) The mechanism of electrochemical 813 dissolution of sphalerite in sulfuric acid media. Electrochim Acta 253: 47-58. 814 https://doi.org/10.1016/j.electacta.2017.09.040 
Kharbish S (2007) A Raman spectroscopic investigation of Fe-rich sphalerite: effect of Fe-

816 substitution. Phys Chem Miner 34: 551-558. https://doi.org/10.1007/s00269-007-0170-x

817 Langman JB, Moberly JG (2018) Weathering of a mined quartz-carbonate, galena-sphalerite ore 818 and release and transport of nanophase zinc carbonate in circumneutral drainage. J Geochem 819 Explor 188: 185-193. https://doi.org/10.1016/j.gexplo.2018.01.024

820 Li Z, Ma Z, Van der Kuijp TJ, Yuan Z, Huang L (2014) A review of soil heavy metal pollution 821 from mines in China: pollution and health risk assessment. Sci Total Environ 468: 843-853. 822 https://doi.org/10.1016/j.scitotenv.2013.08.090

823 Lu Y, Yin W, Huang L, Zhang G, Zhao Y (2011) Assessment of bioaccessibility and exposure 824 risk of arsenic and lead in urban soils of Guangzhou City, China. Environ Geochem Health 33: 825 93-102. https://doi.org/10.1007/s10653-010-9324-8

826 Lu J, Lu H, Lei K, Wang W, Guan Y (2019) Trace metal element pollution of soil and water 827 resources caused by small-scale metallic ore mining activities: a case study from a sphalerite 828 mine in North China. Environ Sci Pollut Res 26: 24630-24644. https://doi.org/10.1007/s11356$829 \quad 019-05703-\mathrm{Z}$

830 Lottermoser BG (2010) Sulfidic mine wastes. In Mine wastes (pp. 43-117). Springer, Berlin, 831 Heidelberg. https://doi.org/10.1007/978-3-642-12419-8_2

832 Malmström ME, Collin C (2004, July) Sphalerite weathering kinetics: effect of ph and particle 833 size. In Proc. 11th Symp. Water-Rock Interaction (Vol. 1, pp. 849-852).

834 Myagkaya IN, Saryg-ool BY, Surkov ON, Zhmodik SM, Lazareva EV, Taran OP (2021) Natural 835 organic matter from the dispersion train of gold sulfide tailings: group composition and 836 fractionation of elements: case study of Ursk Tailings, Kemerovo Region, Siberia. Geochem 837 Explor Environ Anal. https://doi.org/10.1144/geochem2020-052 
838 Meng X, Zhao H, Sun M, Zhang Y, Zhang Y, Lv X, Qiu G (2019) The role of cupric ions in the 839 oxidative dissolution process of marmatite: A dependence on $\mathrm{Cu}^{2+}$ concentration. Sci Total 840 Environ 675: 213-223. https://doi.org/10.1016/j.scitotenv.2019.04.227

841 Mikhlin Y, Karacharov A, Tomashevich Y, Shchukarev A (2016) Interaction of sphalerite with 842 potassium n-butyl xanthate and copper sulfate solutions studied by XPS of fast-frozen samples 843 and zeta-potential measurement. $\quad$ Vacuum $\quad 125:$ 98-105.

844 https://doi.org/10.1016/j.vacuum.2015.12.006

845 Navarro MC, Pérez-Sirvent C Martínez-Sánchez MJ, Vidal J, Tovar PJ, Bech J (2008) 846 Abandoned mine sites as a source of contamination by heavy metals: a case study in a semi-arid 847 zone. J Geochem Explor 96: 183-193. https://doi.org/10.1016/j.gexplo.2007.04.011

848 Osadchii EG, Gorbaty YE (2010) Raman spectra and unit cell parameters of sphalerite solid 849 solutions $\quad\left(\mathrm{Fe}_{\mathrm{x}} \mathrm{Zn}_{1-\mathrm{x}} \mathrm{S}\right) . \quad$ Geochim $\quad$ Cosmochim $\quad$ Acta $\quad 74:$ 568-573. 850 https://doi.org/10.1016/j.gca.2009.10.022

851 Punia A (2021) Role of temperature, wind, and precipitation in heavy metal contamination at 852 copper mines: a review. Environ Sci Pollut Res 28: 4056-4072. https://doi.org/10.1007/s11356$853 \quad 020-11580-8$

854 Puigdomenech I (2015) HYDRA: Hydrochemical Equilibrium-constant Database Software Royal 855 Institute of Technology, Sweden $\quad$ (2004). Google

856 Scholarhttps://sites.google.com/site/chemdiagr/download

857 Razo I, Carrizales L, Castro J, Díaz-Barriga F, Monroy M (2004) Arsenic and heavy metal 858 pollution of soil, water and sediments in a semi-arid climate mining area in Mexico. Water Air 859 Soil Pollut 152: 129-152. https://doi.org/10.1023/B:WATE.0000015350.14520.c1 
860 Robson TC, Braungardt CB, Rieuwerts J, Worsfold P (2014) Cadmium contamination of

861 agricultural soils and crops resulting from sphalerite weathering. Environ Pollut 184: 283-289.

862 https://doi.org/10.1016/j.envpol.2013.09.001

863 Schippers A, Tanne C, Stummeyer J, Graupner T (2019) Sphalerite bioleaching comparison in 864 shake flasks and percolators. Miner Engineer 132: 251-257. 865 https://doi.org/10.1016/j.mineng.2018.12.007

866 Scoble M, Klein B, Dunbar WS (2003) Mining waste: Transforming mining systems for waste 867 management. Int J Surf Min Reclam Environ 17: 123-135. 868 https://doi.org/10.1076/ijsm.17.2.123.14129

869 Shabbir S, Shaari A, Haq BU, Ahmed R, AlFaify S, Ahmed M, Laref A (2021) First-principles 870 investigations of electronic structures and optical spectra of wurtzite and sphalerite types of 871 ZnO1-xSx $\quad(x=0, \quad 0.25, \quad 0.50, \quad 0.75 \quad \& 1)$ alloys. Mater Sci Semicond Process. 872 https://doi.org/10.1016/j.mssp.2020.105326

873 Srinivasan GN, Iyer SV (2000) Cyclic voltammetric studies on sphalerite electrodes. Bull 874 Electrochem 16: 5-9. http://cecri.csircentral.net/id/eprint/933

875 Švancara I, Vytřas K, Barek J, Zima J (2001) Carbon paste electrodes in modern electroanalysis. 876 Crit Rev Anal Chem 31: 311-345. https://dx.doi.org/10.1080/20014091076785

877 Tauson VL, Babkin DN, Lipko SV, Lustenberg EE, Parkhomenko IY, Pastushkova TM, Loginov 878 BA (2010) Partition of heavy metals $(\mathrm{Hg}, \mathrm{Cd}$, and $\mathrm{Pb})$ between sphalerite and hydrothermal 879 solution and the typomorphism of sphalerite surface: XPS, AES, and AFM data. Geochem Int. 880 https://doi.org/10.1134/S0016702910010076 
881 Thomas AN, Root RA, Lantz RC, Sáez AE, Chorover J (2018) Oxidative weathering decreases

882 bioaccessibility of toxic metal (loid) $\mathrm{s}$ in $\mathrm{PM}_{10}$ emissions from sulfide mine tailings. GeoHealth 883 2: 118-138. https://doi.org/10.1002/2017GH000118

884 Urbano G, Meléndez AM, Reyes VE, Veloz MA, González I (2007) Galvanic interactions 885 between galena-sphalerite and their reactivity. Int $\mathrm{J}$ Miner Process 82: 148-155. 886 https://doi.org/10.1016/j.minpro.2006.09.004

887 Wang J, Liu Q, Zeng H (2013) Understanding copper activation and xanthate adsorption on 888 sphalerite by time-of-flight secondary ion mass spectrometry, X-ray photoelectron spectroscopy, 889 and in situ scanning electrochemical microscopy. J Phys Chem C 117: 20089-20097. 890 https://doi.org/10.1021/jp407795k

891 Wang S, Zheng K, Liu Q, Wang L, Feng X, Li H (2021) Galena weathering in simulated alkaline 892 soil: Lead transformation and environmental implications. Sci Total Environ. 893 https://doi.org/10.1016/j.scitotenv.2020.142708

894 Weisener CG, Smart RSTC, Gerson AR (2003) Kinetics and mechanisms of the leaching of low 895 Fe sphalerite. Geochim Cosmochim Acta 67: 823-830. https://doi.org/10.1016/S0016$8967037(02) 01276-0$

897 Voldrichova P, Chrastny V, Sipkova A, Farkas J, Novak M, Stepanova M, Pacherova P (2014) 898 Zinc isotope systematics in snow and ice accretions in Central European mountains. Chem Geol 899 388: 130-141. https://doi.org/10.1016/j.chemgeo.2014.09.008

900 Yang X, Du C, Wan H, Liu Z, Li X (2018) Influence of sulfides on the passivation behavior of 901 titanium alloy TA2 in simulated seawater environments. Appl Surf Sci 458: 198-209. 902 https://doi.org/10.1016/j.apsusc.2018.07.068 
903 Zhao X, Sun Y, Huang J, Wang H, Tang D (2020) Effects of soil heavy metal pollution on 904 microbial activities and community diversity in different land use types in mining areas. Environ 905 Sci Pollut Res 27: 20215-20226. https://doi.org/10.1007/s11356-020-08538-1

906 Zhang Y, Zhao H, Zhang Y, Liu H, Yin H, Deng J, Qiu G (2020) Interaction mechanism between 907 marmatite and chalcocite in acidic (microbial) environments. Hydrometallurgy. 908 https://doi.org/10.1016/j.hydromet.2019.105217

909

910

911

912

913

914

915

916

917

918

919

920

921

922

923 
925 Fig. 1. Chemical leachates evolution during oxidation of the $\mathrm{PbS}-\mathrm{ZnS}$ sample under simulated 926 weathering conditions: $\mathrm{pH}$ (a); oxidation-reduction potential (ORP) (b); sulfates (c), Zn (d), Fe 927 (e) and Cd (f). The standard deviations in the measurements of the present figure are within $15 \%$.

928 Fig. 2. Typical AFM 2D and 3D obtained images during analysis of the pristine (a) and leached $929 \mathrm{PbS}-\mathrm{ZnS}$ surfaces in $0.1 \mathrm{M} \mathrm{NaOH}$ (b), $0.1 \mathrm{M} \mathrm{NaNO}_{3}$ (c), $0.1 \mathrm{M} \mathrm{HClO}_{4}$ (d) or $0.1 \mathrm{M} \mathrm{H}_{2} \mathrm{SO}_{4}$ 930 solution (e). Contact mode.

931 Fig. 3. SEM 2D images obtained during surface analysis of the pristine (a) and leached PbS-ZnS 932 samples in $0.1 \mathrm{M} \mathrm{NaOH}(\mathrm{c}), 0.1 \mathrm{M} \mathrm{NaNO}_{3}$ (d), $0.1 \mathrm{M} \mathrm{HClO}_{4}$ (e) or $0.1 \mathrm{M} \mathrm{H}_{2} \mathrm{SO}_{4}$ (f) solution. 933 This Figure includes SEM 3D image for leached samples in $0.1 \mathrm{M} \mathrm{NaOH}$ conditions, for instance 934 of similar mineral behavior (b). Secondary phases identification is carried out under EDS basis 935 (analyses, $n=10$ ). $\mathrm{ZnS}=$ Sphalerite; $\mathrm{Zn}_{1-\mathrm{x}} \mathrm{S}_{1-\mathrm{y}}=$ Non-stoichiometric-like layers; $\mathrm{PbS}=$ Galena.

936 Fig. 4. Raman spectra obtained during surface analysis of pristine (a) and leached $\mathrm{PbS}-\mathrm{ZnS}$ 937 samples in $0.1 \mathrm{M} \mathrm{NaOH}(\mathrm{c}), 0.1 \mathrm{M} \mathrm{NaNO}_{3}(\mathrm{~d}), 0.1 \mathrm{M} \mathrm{HClO}_{4}$ (e) or $0.1 \mathrm{M} \mathrm{H}_{2} \mathrm{SO}_{4}$ solution (f). 938 Calibration of Si-disc wafer was included for calibration purposes (b). Main Raman peaks are 939 illustrated on the figure.

940 Fig. 5. Zn2p and S2p XPS narrow spectra obtained for pristine and after 24 of leaching PbS-ZnS 941 samples in $0.1 \mathrm{M} \mathrm{NaOH}, 0.1 \mathrm{M} \mathrm{NaNO}_{3}, 0.1 \mathrm{M} \mathrm{HClO}_{4}$ or $0.1 \mathrm{M} \mathrm{H}_{2} \mathrm{SO}_{4}$ solution.

942 Fig. 6. GDOES spectra for pristine and leached PbS-ZnS samples under different simulated 943 weathering conditions for sulfur (a), $\mathrm{Zn} \mathrm{(b),} \mathrm{Fe}(\mathrm{c})$ and $\mathrm{Cd}$ (g) elements. The erosion time is 944 indicated in the Figure. 
946 Fig. 7. Cyclic voltammograms initiated into the positive direction using CPE-PbS-ZnS sample 947 (curves i, fuchsia) and CPE-FeZnS (curves ii) in $0.1 \mathrm{M} \mathrm{NaOH}$ (a, red), $0.1 \mathrm{M} \mathrm{NaNO}_{3}$ (b, blue), $9480.1 \mathrm{M} \mathrm{HClO}_{4}$ (c, green) or $0.1 \mathrm{M} \mathrm{H}_{2} \mathrm{SO}_{4}$ solution (d, black). Scan rate of $5 \mathrm{mV} \cdot \mathrm{s}^{-1}$. The inert 949 response of the CPE without mineral samples (100\% graphite) is included for comparison 950 purposes (intermittent curves iii, gray). Carbon paste and mineral sample contain is 50 wt. $\%$. 951 Ambient conditions. Quiescent systems.

952 Fig. 8. Tafel plots obtained using CPE-PbS-ZnS (50 wt. \%) and FeZnS samples (50 wt. \%) under 953 different simulated weathering conditions: $0.1 \mathrm{M} \mathrm{NaOH}$ (a), $0.1 \mathrm{M} \mathrm{NaNO}_{3}$ (b), $0.1 \mathrm{M} \mathrm{HClO}_{4}(\mathrm{c})$ 954 or $0.1 \mathrm{M} \mathrm{H}_{2} \mathrm{SO}_{4}(\mathrm{~d})$ solution. Scan rate of $1 \mathrm{mV} \cdot \mathrm{s}^{-1}$. Ambient conditions. Stirring conditions of $955300 \mathrm{rpm}$.

956 Fig. 9. Linear sweep voltammetric responses in the positive direction obtained for CPE-FeZnS (a 957 to d) and CPE-PbS-ZnS (a' to d') samples in $0.1 \mathrm{M} \mathrm{NaOH}, 0.1 \mathrm{M} \mathrm{NaNO}_{3}, 0.1 \mathrm{M} \mathrm{HClO}_{4}$ or $0.1 \mathrm{M}$ $958 \mathrm{H}_{2} \mathrm{SO}_{4}$ solution, respectively. Applied anodic pulse $\left(\mathrm{E}_{a}\right)$ is of $1.2 \mathrm{~V} / \mathrm{SCE}$ during 1 and/or $2 \mathrm{~h}$. 959 Scan rate of $20 \mathrm{mV} \cdot \mathrm{s}^{-1}$. Ambient conditions. Quiescent systems.

960

961

962

963

964

965

966 
969 Table 1. Root mean square $(\mathrm{Rq})$ and Roughness $(\mathrm{Ra})$ values collected from different altered 970 sphalerite areas.

971 Table 2. Binding energy (BE), FHWM (Full width at half-maximum), peak areas and chemical state for $972 \mathrm{Zn} 2 \mathrm{p}_{3 / 2}$ and $\mathrm{S} 2 \mathrm{p}_{3 / 2}{ }^{*}$ spectra of pristine and leached sphalerite samples (i.e., PbS-ZnS).

973 Table 3. Kinetic oxidation parameters of the Tafel plots analysis regarding sphalerite oxidation 974 processes in $0.1 \mathrm{M} \mathrm{NaOH}, 0.1 \mathrm{M} \mathrm{NaNO}_{3}, 0.1 \mathrm{M} \mathrm{HClO}_{4}$ or $0.1 \mathrm{M} \mathrm{H}_{2} \mathrm{SO}_{4}$ solution.

975

976

977

978

979

980

981

982

983

984 



Figure 1

Chemical leachates evolution during oxidation of the PbS-ZnS sample under simulated weathering conditions: pH (a); oxidation-reduction potential (ORP) (b); sulfates (c), Zn (d), Fe (e) and Cd (f). The standard deviations in the measurements of the present figure are within $15 \%$. 

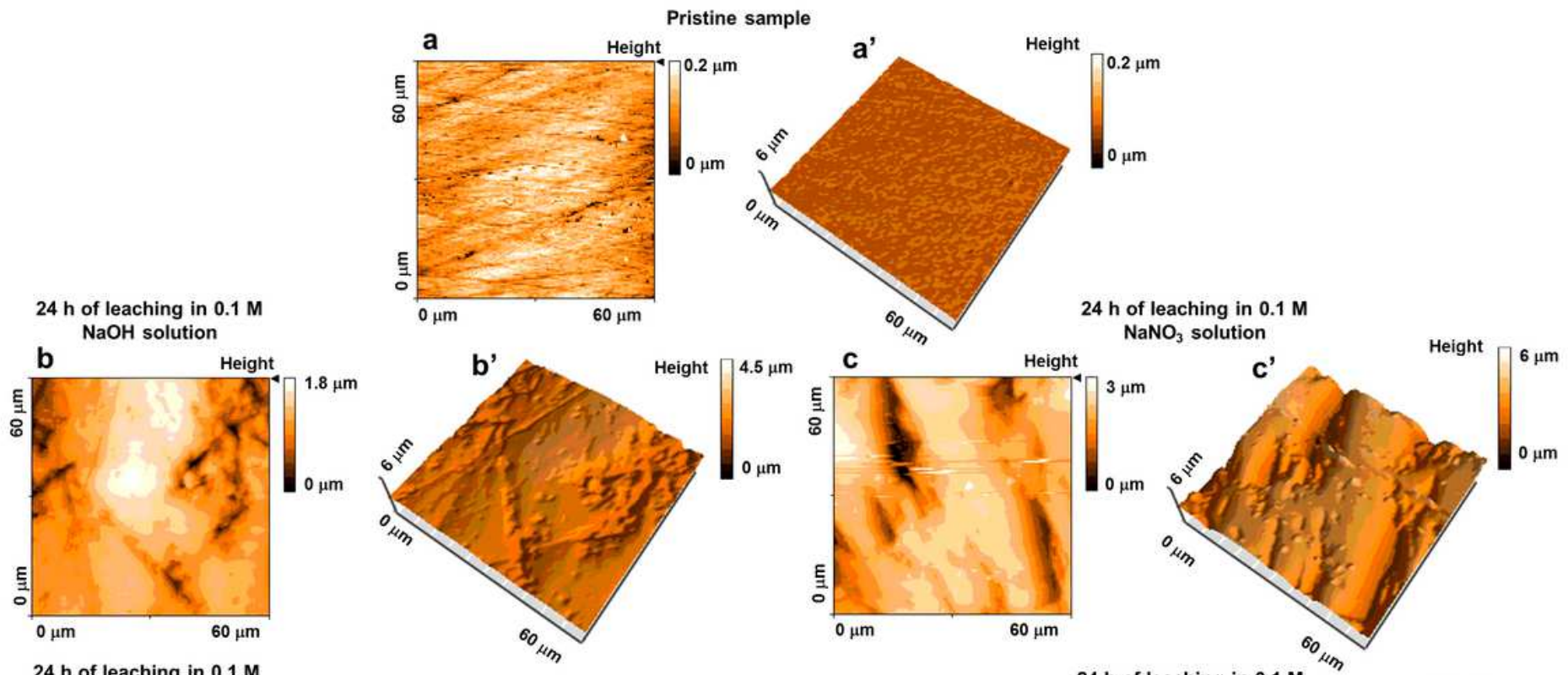

$24 \mathrm{~h}$ of leaching in $0.1 \mathrm{M}$ $\mathrm{HCIO}_{4}$ solution
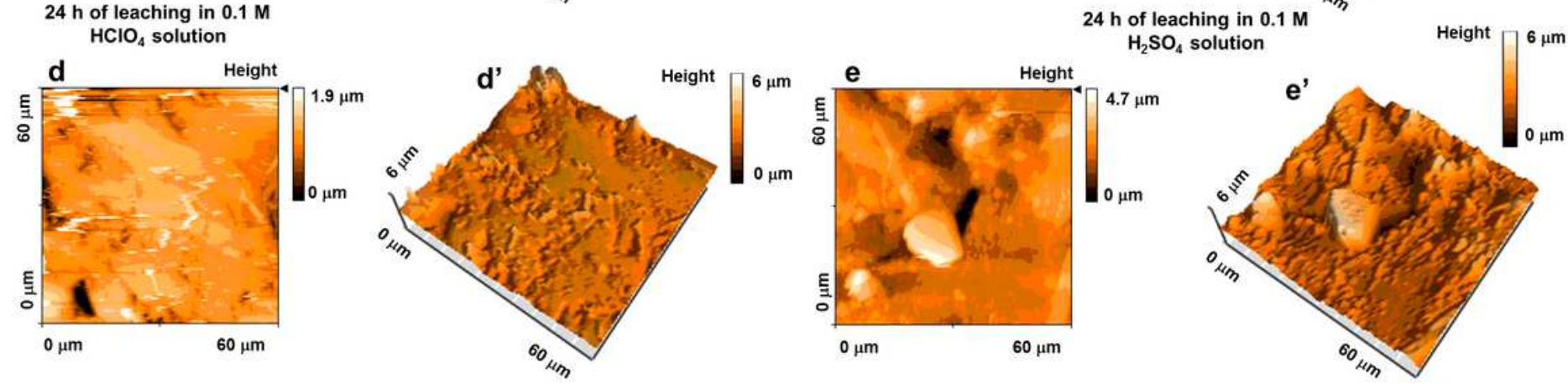

Figure 2

Typical AFM 2D and 3D obtained images during analysis of the pristine (a) and leached PbS-ZnS surfaces in $0.1 \mathrm{M} \mathrm{NaOH}$ (b), $0.1 \mathrm{M} \mathrm{NaNO}_{3}$ (c), $0.1 \mathrm{M} \mathrm{HClO}_{4}$ (d) or $0.1 \mathrm{M} \mathrm{H}_{2} \mathrm{SO}_{4}$ solution (e). Contact mode. 
(a) 2D, Pristine sample

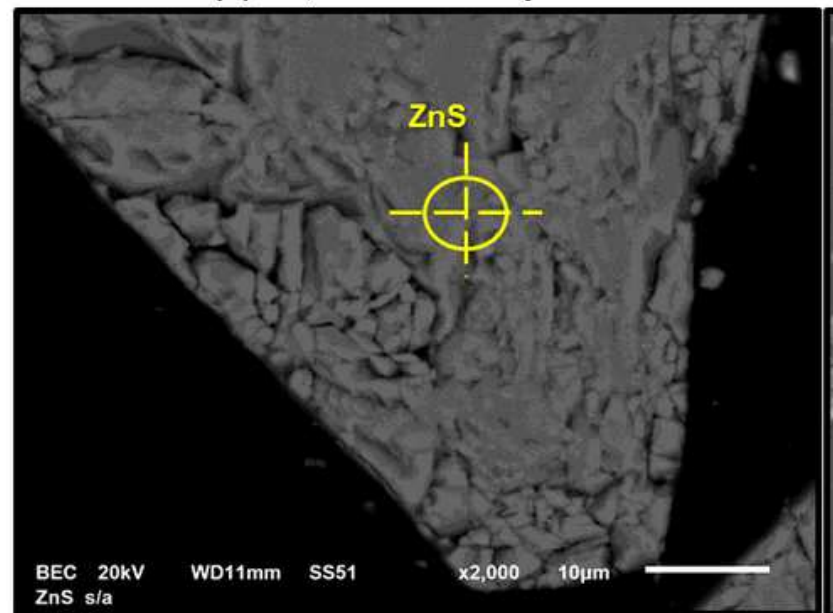

(c) 2D, $24 \mathrm{~h}$ of leaching in $0.1 \mathrm{M} \mathrm{NaOH}$ solution (b) 3D, $24 \mathrm{~h}$ of leaching in $0.1 \mathrm{M} \mathrm{NaOH}$ solution

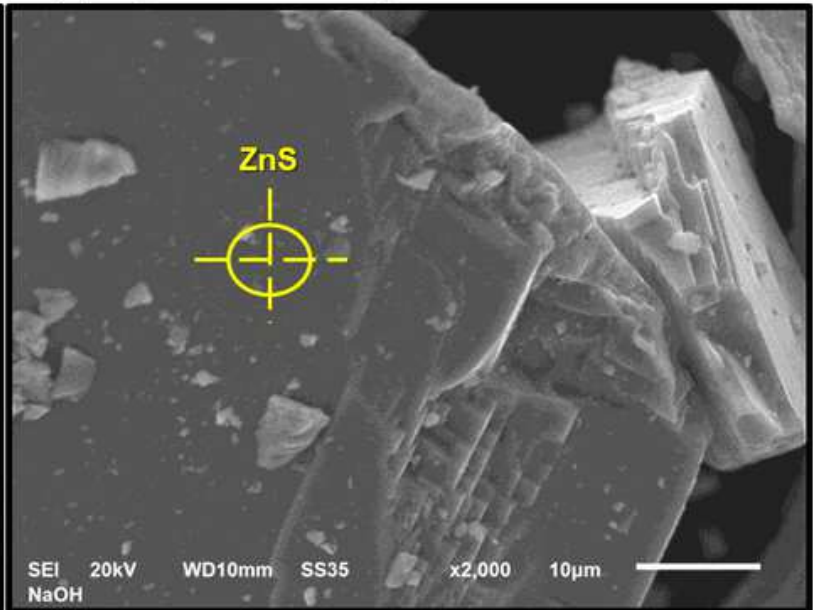

(d) 2D, $24 \mathrm{~h}$ of leaching in $0.1 \mathrm{M} \mathrm{NaNO}$ solution

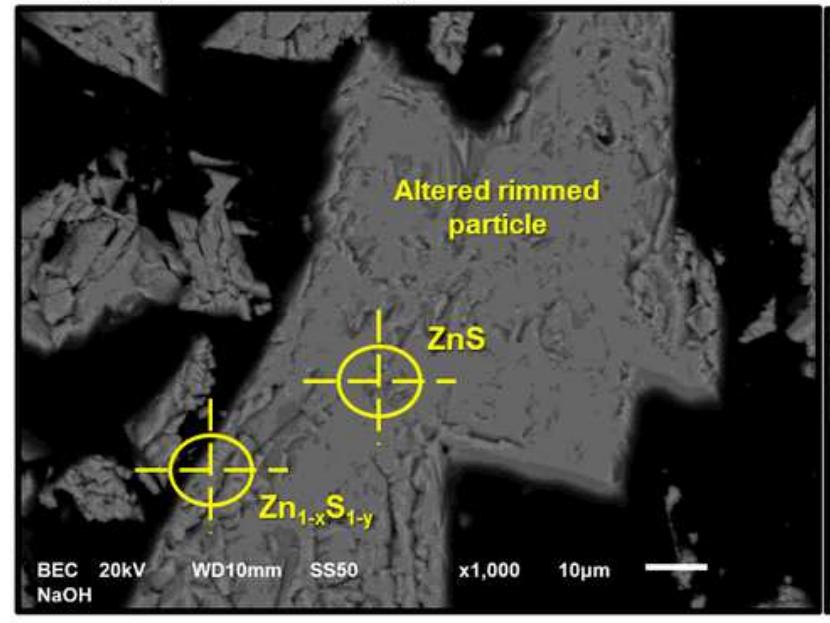

(e) 2D, $24 \mathrm{~h}$ of leaching in $0.1 \mathrm{M} \mathrm{HClO}_{4}$ solution

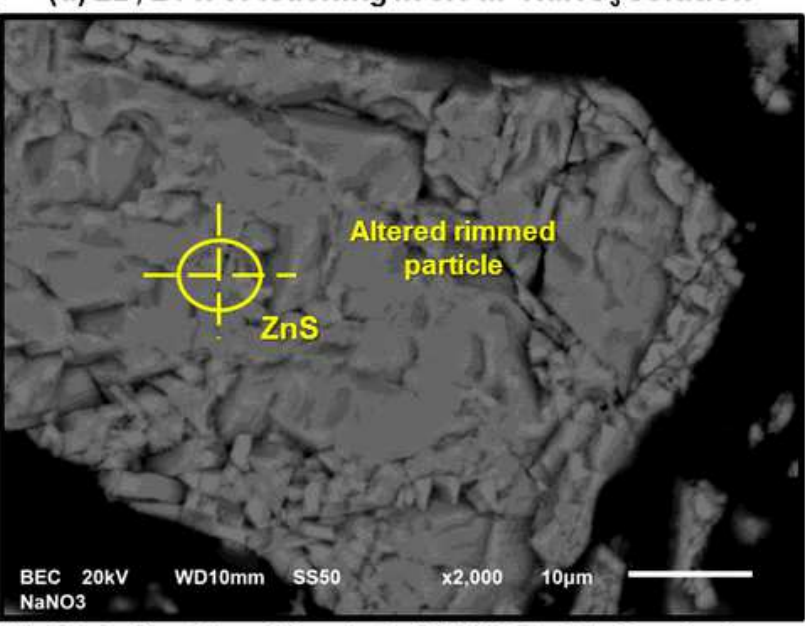

(f) $2 \mathrm{D}, 24 \mathrm{~h}$ of leaching in $0.1 \mathrm{M} \mathrm{H}_{2} \mathrm{SO}_{4} 0.1 \mathrm{M}$ solution
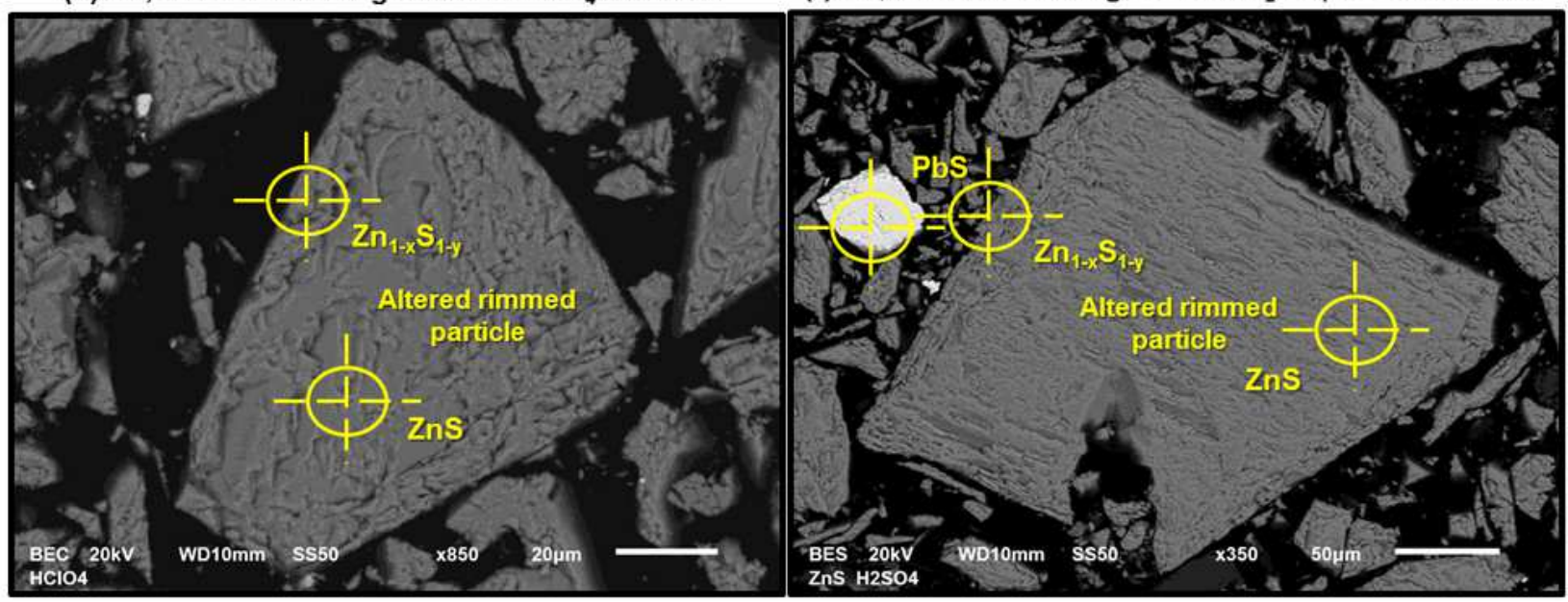

\section{Figure 3}

SEM 2D images obtained during surface analysis of the pristine (a) and leached PbS-ZnS samples in 0.1 $\mathrm{M} \mathrm{NaOH}$ (c), $0.1 \mathrm{M} \mathrm{NaNO}_{3}$ (d), $0.1 \mathrm{M} \mathrm{HClO}_{4}$ (e) or $0.1 \mathrm{M} \mathrm{H}_{2} \mathrm{SO}_{4}$ (f) solution. This Figure includes SEM 3D image for leached samples in $0.1 \mathrm{M} \mathrm{NaOH}$ conditions, for instance of similar mineral behavior (b). Secondary phases identification is carried out under EDS basis (analyses, $n=10$ ). $Z n S=S$ phalerite; $Z_{1}$. $\mathrm{x}_{1-\mathrm{y}}=$ Non-stoichiometric-like layers; $\mathrm{PbS}=$ Galena. 

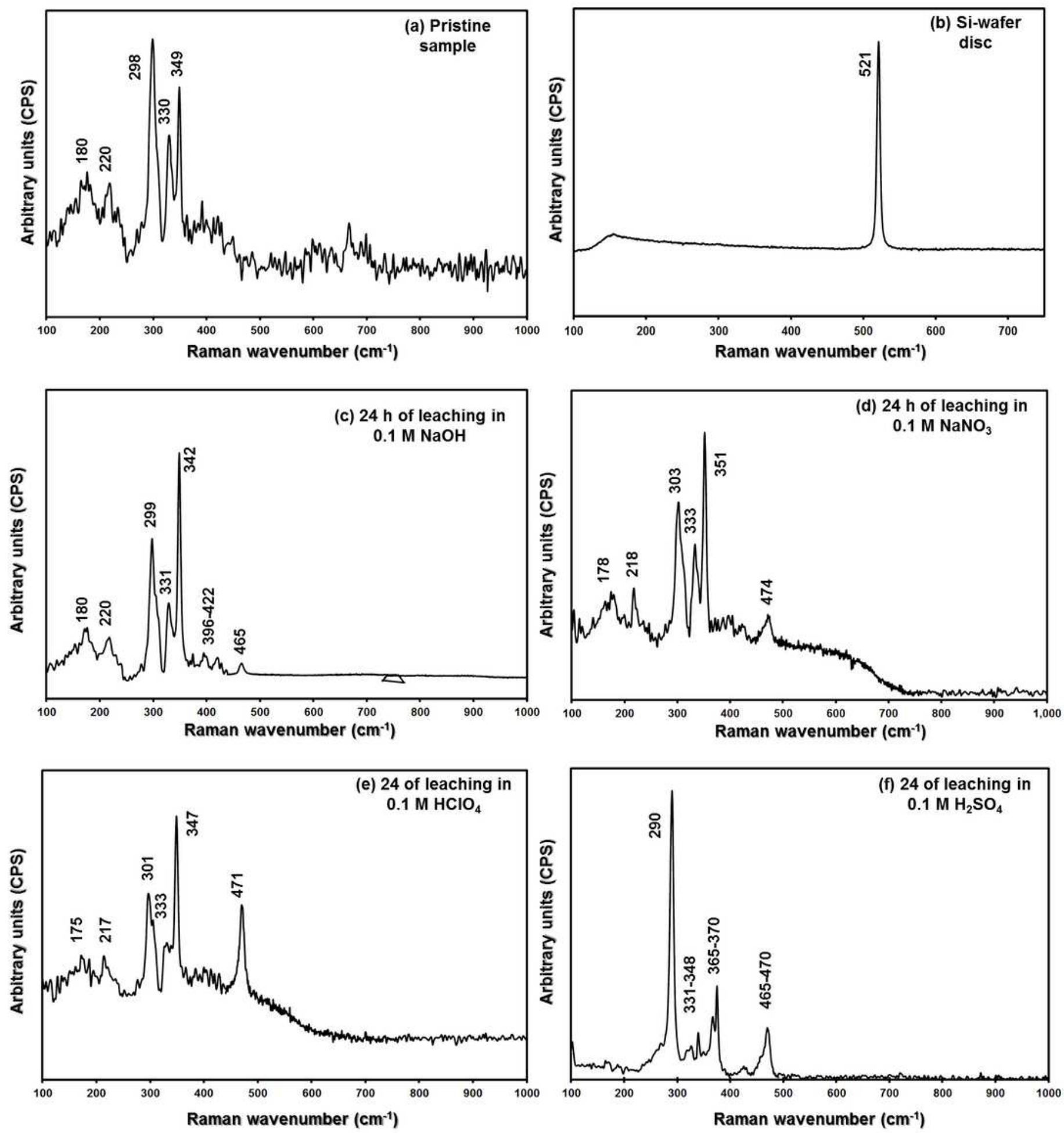

Figure 4

Raman spectra obtained during surface analysis of pristine (a) and leached PbS-ZnS samples in $0.1 \mathrm{M}$ $\mathrm{NaOH}$ (c), $0.1 \mathrm{M} \mathrm{NaNO}_{3}$ (d), $0.1 \mathrm{M} \mathrm{HClO}_{4}$ (e) or $0.1 \mathrm{M} \mathrm{H}_{2} \mathrm{SO}_{4}$ solution (f). Calibration of Si-disc wafer was included for calibration purposes (b). Main Raman peaks are illustrated on the figure. 

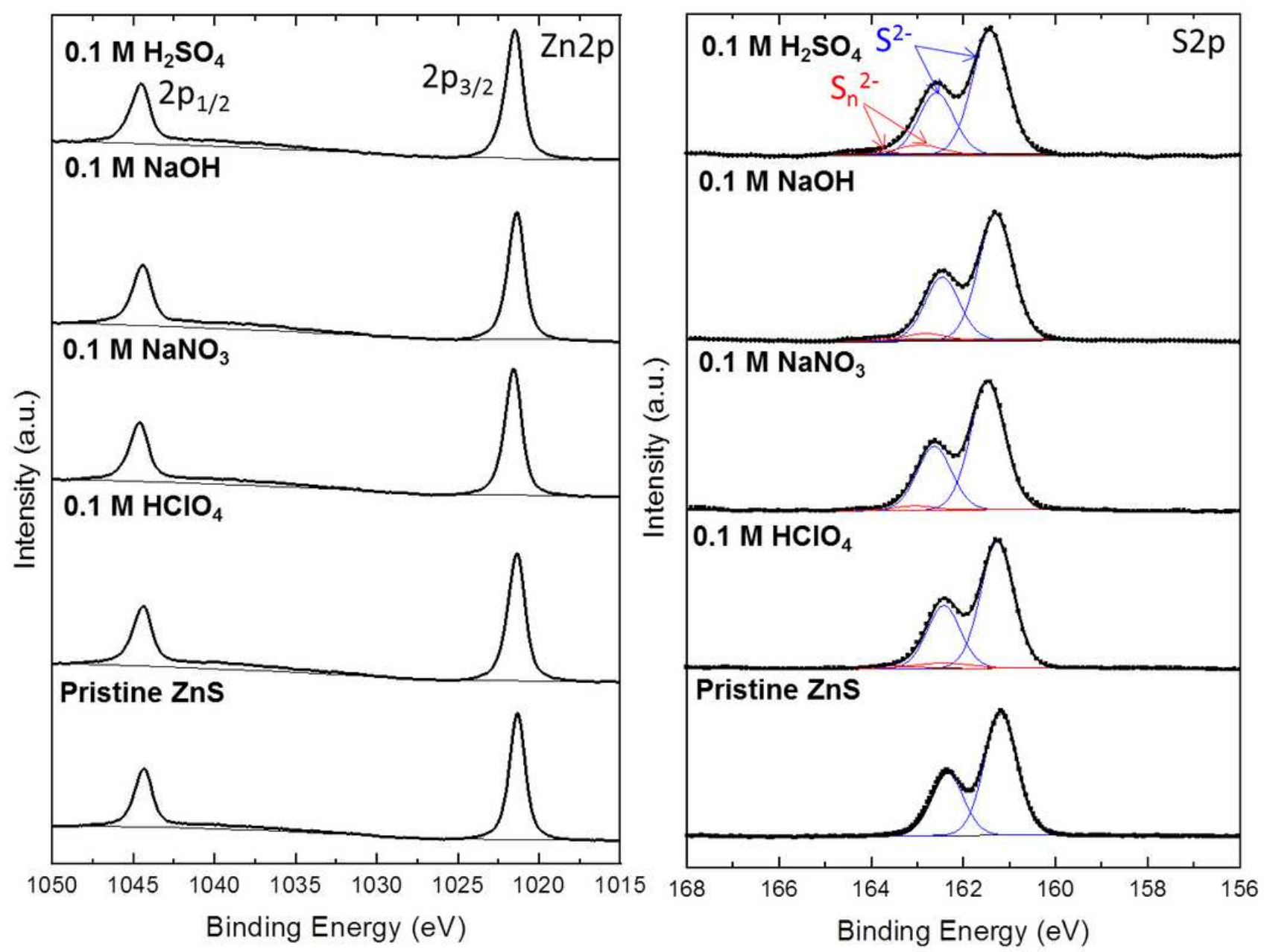

Figure 5

$\mathrm{Zn} 2 \mathrm{p}$ and S2p XPS narrow spectra obtained for pristine and after 24 of leaching PbS-ZnS samples in 0.1 $\mathrm{M} \mathrm{NaOH}, 0.1 \mathrm{M} \mathrm{NaNO}_{3}, 0.1 \mathrm{M} \mathrm{HClO}_{4}$ or $0.1 \mathrm{M} \mathrm{H}_{2} \mathrm{SO}_{4}$ solution. 

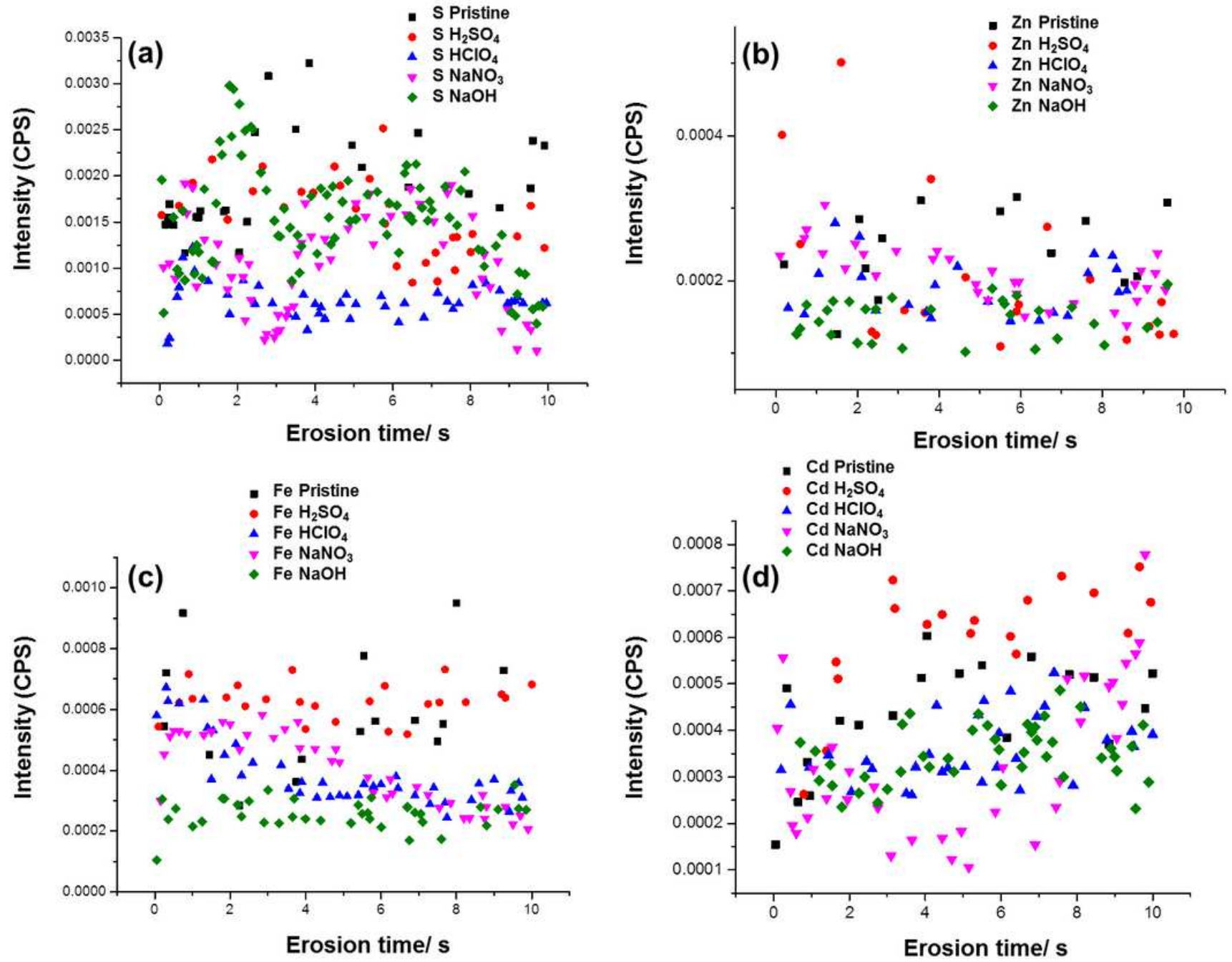

Figure 6

GDOES spectra for pristine and leached PbS-ZnS samples under different simulated weathering conditions for sulfur (a), Zn (b), Fe (c) and Cd (g) elements. The erosion time is indicated in the Figure. 

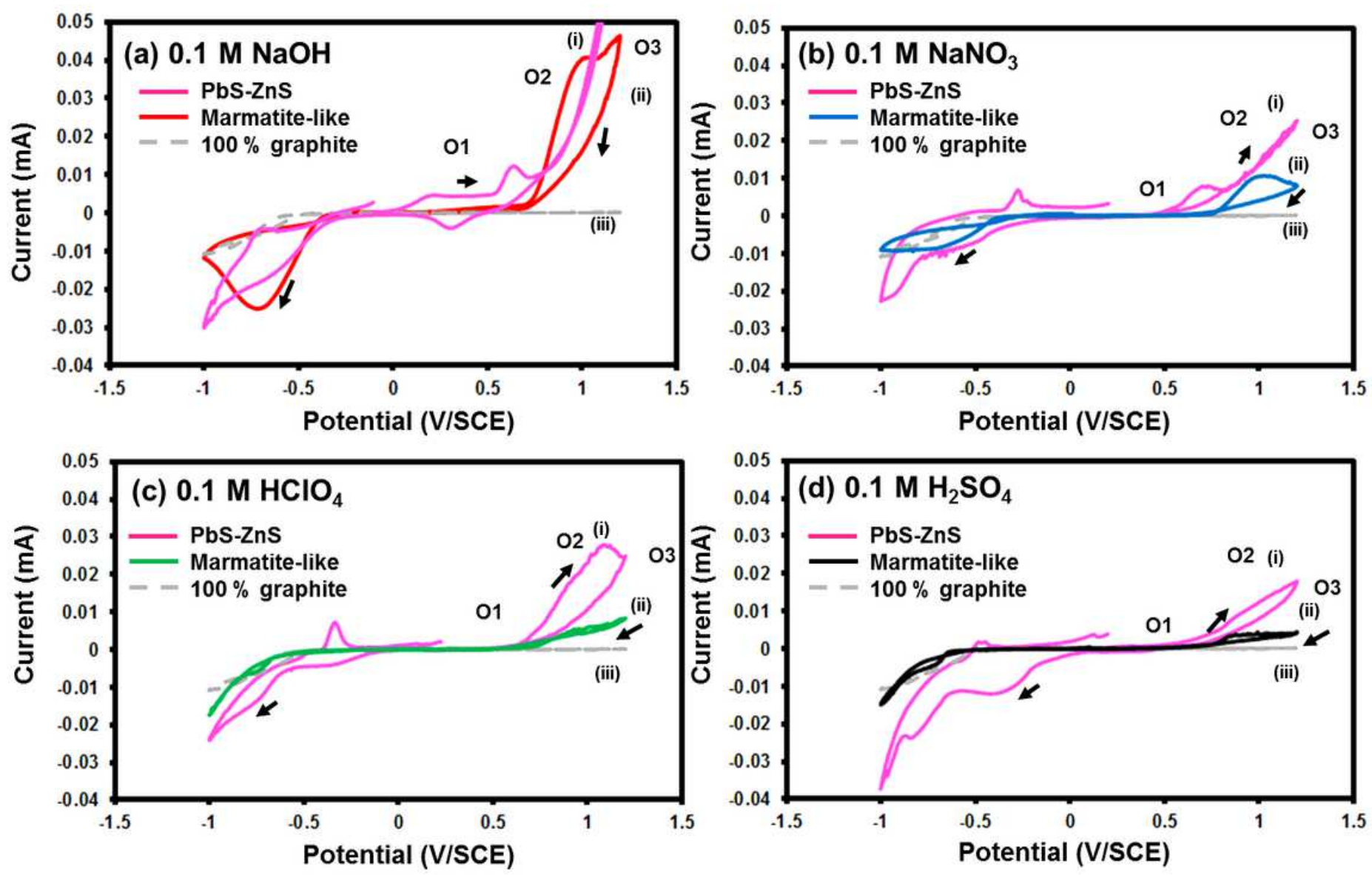

Figure 7

Cyclic voltammograms initiated into the positive direction using CPE-PbS-ZnS sample (curves $\mathrm{i}$, fuchsia) and CPE-FeZnS (curves ii) in $0.1 \mathrm{M} \mathrm{NaOH}$ (a, red), $0.1 \mathrm{M} \mathrm{NaNO}_{3}$ (b, blue), $0.1 \mathrm{M} \mathrm{HClO}_{4}$ (c, green) or $0.1 \mathrm{M}$ $\mathrm{H}_{2} \mathrm{SO}_{4}$ solution (d, black). Scan rate of $5 \mathrm{mV} \cdot \mathrm{s}^{-1}$. The inert response of the CPE without mineral samples (100\% graphite) is included for comparison purposes (intermittent curves iii, gray). Carbon paste and mineral sample contain is $50 \mathrm{wt}$. \%. Ambient conditions. Quiescent systems. 

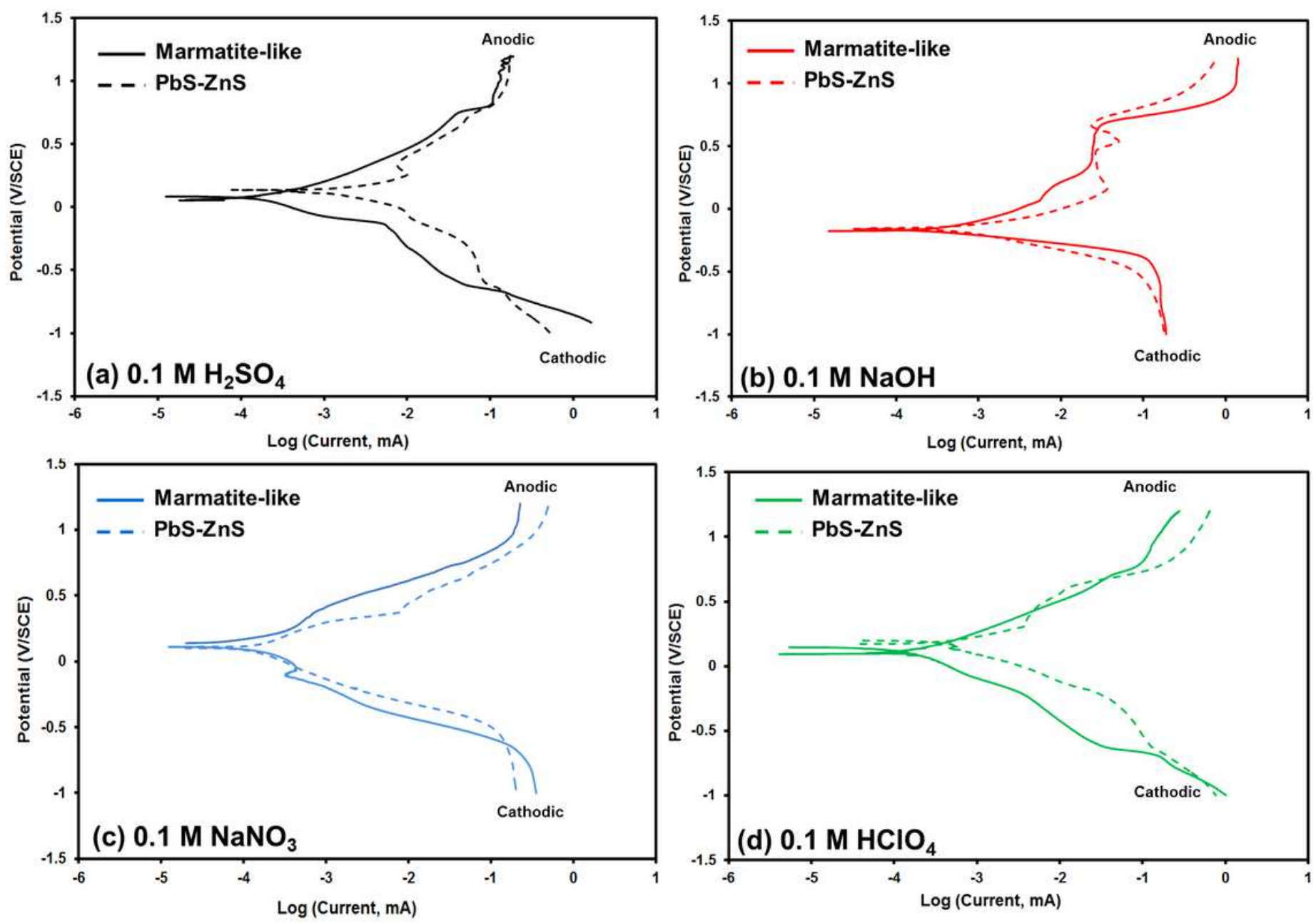

Figure 8

Tafel plots obtained using CPE-PbS-ZnS (50 wt. \%) and FeZnS samples (50 wt. \%) under different simulated weathering conditions: $0.1 \mathrm{M} \mathrm{NaOH}$ (a), $0.1 \mathrm{M} \mathrm{NaNO}_{3}$ (b), $0.1 \mathrm{M} \mathrm{HClO}_{4}$ (c) or $0.1 \mathrm{M} \mathrm{H}_{2} \mathrm{SO}_{4}$ (d) solution. Scan rate of $1 \mathrm{mV} \cdot \mathrm{s}^{-1}$. Ambient conditions. Stirring conditions of $300 \mathrm{rpm}$. 

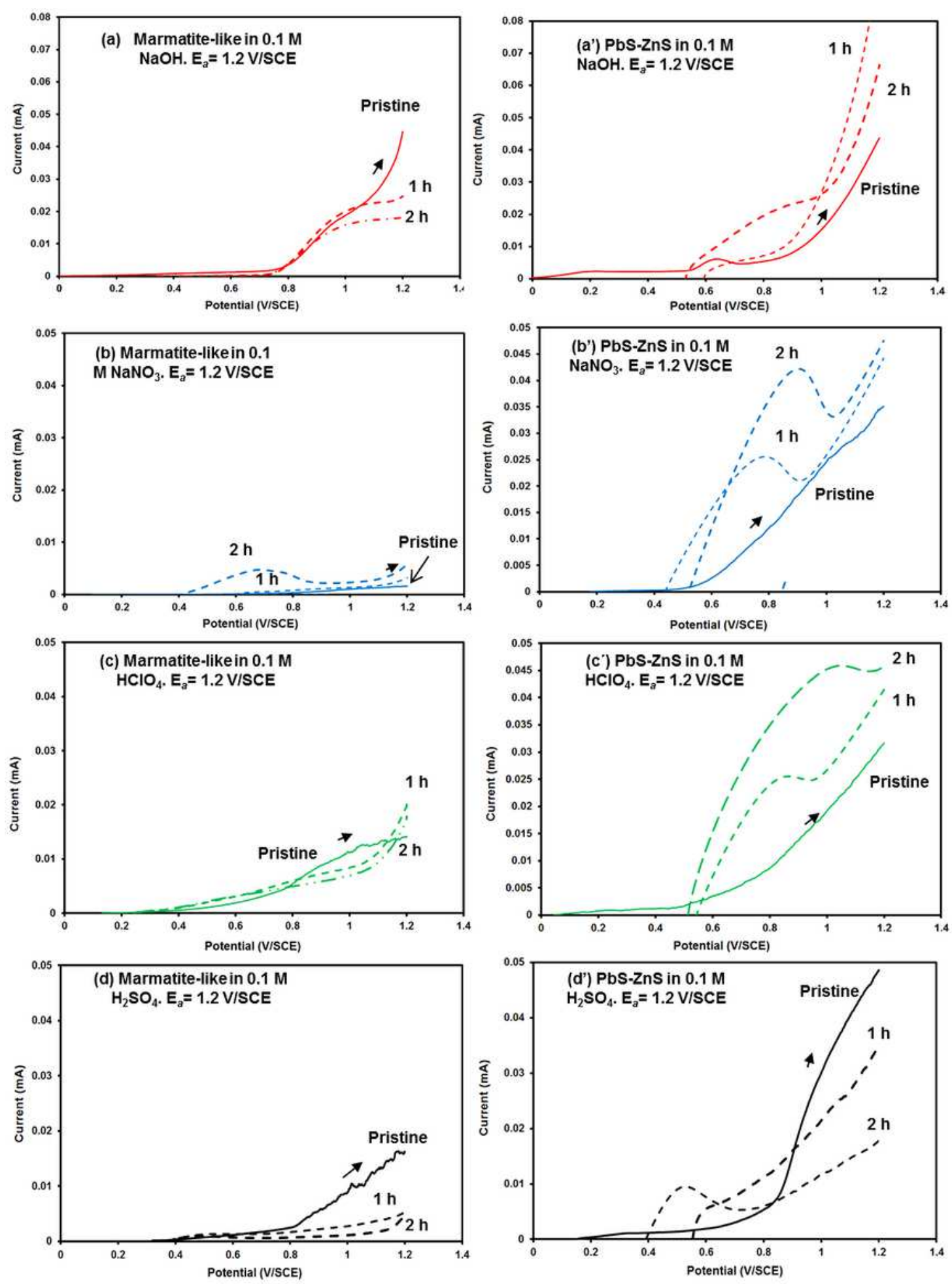

\section{Figure 9}

Linear sweep voltammetric responses in the positive direction obtained for CPE-FeZnS (a to d) and CPEPbS-ZnS (a' to d') samples in $0.1 \mathrm{M} \mathrm{NaOH}, 0.1 \mathrm{M} \mathrm{NaNO}_{3}, 0.1 \mathrm{M} \mathrm{HClO}_{4}$ or $0.1 \mathrm{M} \mathrm{H}_{2} \mathrm{SO}_{4}$ solution, respectively. Applied anodic pulse $\left(E_{a}\right)$ is of $1.2 \mathrm{~V} / \mathrm{SCE}$ during 1 and/or $2 \mathrm{~h}$. Scan rate of $20 \mathrm{mV} \cdot \mathrm{s}^{-1}$. Ambient conditions. Quiescent systems. 


\section{Supplementary Files}

This is a list of supplementary files associated with this preprint. Click to download.

- Supplementarymaterial.docx 